\title{
What Makes Genetic Discrimination Exceptional?
}

Deborah Hellman ${ }^{\dagger}$

\section{INTRODUCTION}

Recent advances in understanding the genetic basis of disease has inspired hope but also fear. While establishing a link between a person's genetic makeup and a propensity to disease may lead to better treatment, many scientists, physicians and genetic counselors also worry that it may lead to discrimination. Although access to health insurance is the primary concern, people also fear discrimination in life and disability insurance, employment and other contexts, such as child custody decisions or adoption. In response to this concern, many state legislatures have passed laws forbidding genetic discrimination.' While most of these laws focus on health insurance, ${ }^{2}$ some also prohibit genetic discrimination in employment ${ }^{3}$ or in life or disability insurance coverage. ${ }^{4}$

$\uparrow \quad$ Associate Professor, University of Maryland School of Law. B.A., Dartmouth College; M.A. in Philosophy, Columbia University; J.D., Harvard Law School. I want to thank Ryan Lemmerbrock for his excellent research assistance.

1 Most of the fifty states have passed laws prohibiting genetic discrimination in health insurance and employment. For charts depicting states and their respective legislation, see both National Conference of State Legislatures (NCSL), State Genetic Discrimination in Health Insurance Laws, available at http://www.ncsl.org/programs/health/genetics/ndishlth.htm (Aug. 7, 2002), and NCSL, State Genetics Employment Laws, available at http://www.ncsl.org/programs/health/genetics /ndiscrim. htm (Aug. 8, 2002).

2 Forty-six of the fifty states have enacted laws prohibiting such genetic discrimination by insurers. NCSL, State Genetic Discrimination in Health Insurance Laws, supra note 1. Examples of insurer practices which are prohibited include: the use of genetic information for risk selection or risk classification purposes, the establishment of eligibility rules based on genetic information and the requirement of genetic tests. $I d$. Many states prohibit all of the above practices in individual and group policies; however, a small number of states prohibit certain practices in group policies only. Id.

3 Thirty-one of the fifty states have enacted laws prohibiting genetic discrimination in employment. NCSL, State Genetic Discrimination in Health Insurance Laws, supra note 1. As with the prohibitions in health insurance, the scope of what is impermissible in the employment context varies widely. See id. (noting that examples of prohibitions include requesting or requiring genetic information, performing genetic tests and obtaining genetic test results). All states that have such legislation prohibit discrimination based on the results of genetic tests, and most states prohibit employers from accessing such information or conducting their own genetic tests. $I d$.

4 Seventeen states curtail discrimination in life or disability insurance coverage. NCSL, State Genetic Nondiscrimination Laws in Life, Disability, and Long-term Care Insurance, available at http://www.ncsl.org/programs/health/genetics/ndislife.htm (Oct. 14, 2002). These states' laws do not expressly prohibit, but rather restrict insurer use of genetic information in some manner. See id. For example, four states prohibit discrimination in life and disability insurance without actuarial justification. Id. 
These laws have been the subject of both praise and criticism. Defenders of the laws see them as important and necessary, though arguably incomplete. ${ }^{5}$ Critics view them as unjustified and unwarranted. ${ }^{6}$ However, the question that dominates current literature is whether genetic discrimination is meaningfully different from discrimination on the basis of general health status; or as the debate is often framed, whether anti-discrimination laws ought to be genetic or generic. ${ }^{7}$ In fact, this is one point on which there is some convergence between the critics and supporters of antidiscrimination laws. Critics of the current laws that target genetic discrimination argue that genetic discrimination is no different from discrimination on the basis of health status and, additionally, that such discrimination is necessarily at the heart of the proper administration of insurance. ${ }^{8}$ Therefore, these critics argue, the current laws are both unwise and unjust. Some supporters of anti-discrimination protection acknowledge that there is no good reason to differentiate between those with a genetic predisposition to disease and those who already suffer from disease. However, rather than concluding that no anti-discrimination laws are necessary, these commentators see the current laws as merely a first step in the right direction. The second step, then, would be a generic law that protects people from discrimination on the basis of health status.

This Article also addresses the question of whether special genetics legislation is warranted. In other words, why treat discrimination on the basis of genetic variation differently from discrimination on the basis of health? Although scholars offer a myriad of arguments in support of laws prohibiting genetic discrimination, most of these arguments fail to justify the need for genetic (as opposed to generic) legislation.

5 See, e.g., Trudo Lemmens, Selective Justice, Genetic Discrimination, and Insurance: Should We Single Out Genes in Our Laws?, 45 MCGILL L.J. 347, 383 (2000) (arguing that access to health insurance should not depend on health status, whether of genetic or non-genetic origin).

6 See, e.g., Colin S. Diver \& Jane Maslow Cohen, Genophobia: What is Wrong with Genetic Discrimination?, 149 U. PA. L. REV. 1439, 1445-446 (2001) (arguing that laws banning genetic discrimination are unjust both because they will "cause significant welfare losses due to the distortion of allocative efficiency" and because they "selectively favor[] a single type of moral 'bad luck,' while concealing both the extent and the form of its intended cross-subsidies"); Richard A. Epstein, The Legal Regulation of Genetic Discrimination: Old Responses to New Technology, 74 B.U. L. REV. 1, 18 (1994) (stating that "the prohibition against genetic discrimination should be seen for what it isan elaborate set of cross-subsidies that reduces the total level of social wealth as it transfers wealth between parties"); Robert J. Pokorski, Use of Genetic Information by Private Insurers, in JUSTICE AND THE Human GenOME PROJeCt 91, 97 (Timothy F. Murphy \& Marc A. Lappé eds., 1994) (arguing that prohibiting genetic discrimination by insurers is unjust because "[t]his mandated subsidization of unfavorable risks by good risks would be tantamount to an indirect governmental tax levied solely against insurance policyholders and stockholders").

7 Mark A. Rothstein \& Mary R. Anderlik, What Is Genetic Discrimination, and When and How Can It Be Prevented?, 3 GENETiCs MED. 354, 357 (2001) (arguing that laws specially targeting genetic discrimination as distinct from health status-based discrimination are both unjust and impratical); Sonia M. Suter, The Allure and Peril of Genetic Exceptionalism: Do We Need Special Genetics Legislation?, 79 WASH. U. L.Q. 669 (2001) (claiming that genetic information is not so qualitatively different from other medical information that it warrants special legislation and that law makers should take a more comprehensive approach to health-status discrimination); Susan M. Wolf, Beyond "Genetic Discrimination": Toward the Broader Harm of Geneticism, 23 J.L. MED. \& ETHICS 345,347 (1995) (arguing that laws forbidding genetic discrimination are overly narrow because the "social practice that needs to be changed is broader than health insurers' accurate use of genetic tests and information").

$8 \quad$ See T.H. Cushing, Should There be Genetic Testing in Insurance Risk Classification?, 60 DEF. COUNS. J. 249, 253 (1993) (noting that insurers underwrite policies in accordance with factors known to effect life expectancy and "[f]rom the health and life insurers' point of view, genetic testing [is] useful in assessing the risks they will underwrite."). 
There are, however, two reasons for specifically targeting genetic discrimination that warrant further exploration. The first of these-that legislation prohibiting genetic discrimination is needed in order to safeguard the health benefits that the new genetic science offers-is powerful and important. But, it is more complex than has been thus far recognized. This Article will examine that argument in depth, and argue that the strength of the argument depends on the answers to several empirical questions that require further study.

The second argument that warrants a closer look-which implicitly underlies many of the arguments in the literature on genetic discrimination-has neither been teased out nor examined explicitly. Genetic discrimination may be meaningfully different (and worse) than health status discrimination because of what it expresses. This claim rests on the more general claim that the expressive dimension of action matters morally and legally. ${ }^{9}$ In arguing for protection from genetic discrimination, commentators commonly refer to the history of eugenics both in this country and in Europe, particularly Nazi Germany. However, this reference is made in a cursory fashion without any articulation of why that history matters or what part it plays in building an argument for legislation prohibiting genetic discrimination. This Article will fill that gap by developing the argument that because the social meaning of treating people differently on the basis of their genetic make-up is different from the social meaning of discrimination on the basis of health or illness, special legislation is warranted to prohibit genetic discrimination.

Interestingly, in the related context of prenatal genetic testing, disability rights activists offer a critique that focuses on the meaning expressed by the routine nature of genetic testing in prenatal care. ${ }^{10}$ Because this argument rests squarely on the expressive dimension of these actions and because both its strengths and weaknesses have been well-developed, ${ }^{11}$ albeit outside of the legal literature, it provides an illustration that will be useful to the examination of the related claim that genetic discrimination by insurers, employers and others is especially wrongful because of what it expresses.

This Article begins by addressing an important preliminary issue regarding the problem of definition. Can one define "genetic discrimination" in a way that adequately differentiates it from health status discrimination? This leads to the central question of whether genetic discrimination is meaningfully different from discrimination on the basis of health. And, if so, do these differences provide good reasons to specially prohibit genetic discrimination? This Article briefly summarizes the familiar arguments for forbidding genetic discrimination as well as the familiar replies. Next, it examines the claim that laws forbidding genetic discrimination are warranted to ensure that fears of genetic discrimination do not thwart the promise of genetic science. While this argument is not new, its complexities have not as yet been adequately explored. Finally, the Article focuses on the claim that genetic discrimination is different because it expresses a morally

9 Deborah Hellman, The Expressive Dimension of Equal Protection, 85 MINN. L. REV. 1 (2000) [hereinafter Hellman, Expressive Dimension] (arguing that a state law or policy violates the Equal Protection clause if it expresses a meaning that conflicts with the government's obligation to treat each person with equal concern and respect); Deborah Hellman, Judging by Appearances: Professional Ethics, Expressive Government and the Moral Significance of How Things Seem, 60 MD. L. REV. 653 (200l) (examining whether there are non-consequentialist reasons to be concerned about the appearance of impropriety).

10 See Prenatal Testing and Disability Rights (Erik Parens \& Adrienne Ashe eds., 2000) [hereinafter PRENATAL TESTING].

11 Id. 
problematic meaning-an argument that underlies critiques found in the literature, but which has not yet been clearly articulated or evaluated.

\section{DEFINITIONAL PRELIMINARIES}

Some critics of prohibitions on genetic discrimination favor a generic antidiscrimination approach (in the form of general protections of medical privacy, for example) because they believe it is theoretically or practically impossible to distinguish genetic discrimination from discrimination on the basis of general health. ${ }^{12}$ This is a common and well-articulated critique that will be summarized only briefly here. If laws define genetic discrimination as discrimination on the basis of the results of a test of a person's genetic material, such as an examination of DNA, the laws will fail to capture many instances of discrimination on the basis of genetic predisposition to disease. For example, a family medical history, which is the obvious starting point of any medical record or doctor's visit, contains a wealth of information about a person's genetic predisposition to disease. Yet, this information is not the product of any new or sophisticated DNA test. As a result, those state laws that define "genetic information" as information resulting from a test of DNA have been criticized as overly narrow. ${ }^{13}$

This critique has led to a second wave of legislation prohibiting genetic discrimination. ${ }^{14}$ These laws define "genetic information" more broadly. For example, in Maryland, "[a]n insurer, nonprofit health service plan, or health maintenance organization may not: use a genetic test, or the results of a genetic test, genetic information, or a request for genetic services to reject, deny, limit, cancel, refuse to renew, increase the rates of, affect the terms or conditions of, or otherwise affect a health insurance policy or contract." ${ }^{\text {"IS }}$ This approach has its own problems however. The definition has become so broad that it seemingly prohibits almost all forms of discrimination on the basis of health, except perhaps illness or disability caused by accident. As we learn more about the genetic components of common illnesses, scientists are discovering that most diseases are, at least in part, influenced by our genes. As a result, common tests ordinarily not labeled "genetic tests," such as a blood pressure reading, arguably fall within the purview of these new laws. As Dr. Thomas Murray reports, the lack of a clear line between genetic and non-genetic diseases was one of the central reasons why the Task Force on Genetic Information and Insurance for the Human Genome Project rejected what he terms "genetic exceptionalism"- the view that genetic discrimination is different and therefore

12 See, e.g., Diver \& Cohen, supra note 6, at 1451; Lemmens, supra note 5, at 368-69; Thomas H. Murray, Genetic Exceptionalism and "Future Diaries": Is Genetic Information Different from other Medical Information?, in GENETIC SECRETS 60, 68-9 (1997); Rothstein \& Anderlik, supra note 7 , at 357 .

13 See, e.g., Henry T. Greely, Genotype Discrimination: The Complex Case For Some Legislative Protection, 149 U. PA. L. REV. 1483, $1495-497$ (2001), Lemmens, supra note 5, at 368; Karen H. Rothenberg, Genetic Information and Health Insurance: State Legislative Approaches, 23 J.L. MED. \& ETHICS 312, 317 (1995).

14 See, e.g., CAL. INS. CODE ANN. \$10123.3 (West 1993); Colo. Rev. STAT. § 10-3-1104.7 (2002); GA. CODE ANN. \$33-54-1 (1996); 410 ILL. COMP. STAT. 513/10-513/45 (1997); Mo. ANN. STAT. $\$ \$ 375.1300-375.1312$ (West 2002); N.Y. INS. LAW $\$ 2612$ (McKinney 2000 \& Supp. 2003); OR. REV. STAT. $\$ 746.135$ (2001); R.I. GEN. LAWS $\$ 27-18-52$ (2002); TENN. CODE ANN. § 56-7-2701 (2000).

15 MD. Code ANN., INS. \$27-909(c)(1) (1997 \& Supp. 2002). 
warrants special prohibitory legislation. ${ }^{16}$ Consequently, many scholars argue against laws that specially target genetic discrimination for the practical reason that their goal is futile.

Professor Henry Greely provides a helpful resolution to this definitional problem. Greely proposes that legislation should draw a distinction between discrimination on the basis of genotype and discrimination on the basis of phenotype. $^{17}$ In his measured support for limited federal legislation prohibiting genetic discrimination in health insurance and employment, Greely suggests that such a law forbid health insurers from charging higher rates on the basis of information about unexpressed genetic traits, regardless of the source of the information. As he explains, "[g]enetic information should thus be defined broadly to encompass any .. . information that provides probabilitic information about a person's genotype .. . from genetic tests, other medical tests, family history, diagnoses of traits or conditions, or the taking of (or even making inquires about) a genetic test." In order to avoid also forbidding discrimination on the basis of health status generally, Greely proposes allowing discrimination when the trait has already manifest in the form of illness or disability. ${ }^{19}$ Drawing the line in this way avoids what Greely calls the "feedback effect," when broadly drawn legislation could allow someone with a genetic disease like Huntington's disease to sue for genetic discrimination if he is denied coverage on the basis of having that illness. ${ }^{20}$ For Greely, once the genetic predisposition is manifest as illness or in the form of a medically relevant symptom, it would not be forbidden. ${ }^{21}$

Greely's resolution of the definitional dilemma adopts the meaning originally proposed by Paul Billings and his colleagues in an early piece on genetic discrimination. $^{22}$ In Greely's view, the definition is "conceptually straightforward though perhaps complicated to implement." 23 At least at first blush, his distinction seems workable, but is it defensible? Whether this definition is satisfactory depends on what moral justification is offered for enacting legislation specifically forbidding "genetic discrimination." The definition of "genetic discrimination" and the moral argument for forbidding genetic discrimination are, obviously, intimately

16 Murray, supra note 12, at 68 (explaining that the task force could not find a clear distinction between genetic and non-genetic information because in most cases "the two-bucket theory [to wit, putting specific diseases or conditions in either a genetic or non-genetic 'bucket'] was hopelessly inadequate").

17 Greely, supra note 13, at 1502-503.

18 Id. at 1502.

19 Id. at $1502-503$.

$20 \quad$ Id. at 1497.

21 Greely admits that the distinction may be complicated to implement as many genetic predispositions are manifest in the body in ways that are not harmful before they cause disease. Id. at 1503-504. To delineate which conditions count as discrimination on the basis of phenotype, and are therefore permitted, and which are discrimination on the basis of genotype, and are therefore prohibited, Greely proposes the concept of the "medically significant symptoms." Id. at 1504 . As I understand his proposal, if the phenotypic difference is medically significant as a symptom of the illness to come, then discrimination on the basis of that difference is permitted.

22 Paul R. Billings defines "genetic discrimination" as "discrimination against an individual or against members of that individual's family solely because of real or perceived differences from the normal genome of that individual. Genetic discrimination is distinguished from discrimination based on disabilities caused by altered genes by excluding, from the former category, those instances of discrimination against an individual who at the time of the discriminatory act was affected by the genetic disease." Paul R. Billings et al., Discrimination as a Consequence of Genetic Testing, 50 AM. J. HUM. GENETICS 476, 477 (1992).

23 Greely, supra note 13, at 1503. 
intertwined, or at least they ought to be. Since Greely's resolution draws a distinction between discrimination on the basis of unexpressed genetic traits and discrimination on the basis of manifested illness, whether of genetic or non-genetic etiology, the reasons for distinguishing between genetic and non-genetic discrimination must make such a definition both sensible and warranted. This issue will be addressed after an examination of the moral grounds for distinguishing genetic discrimination from other forms of health status discrimination.

\section{IS GENETIC DISCRIMINATION DIFFERENT?}

At the heart of the question of whether genetic discrimination ought to be prohibited lies the issue of whether discrimination on the basis of genetic information is morally different from discrimination on the basis of health or illness. At present, a person who is sick may be charged higher insurance rates or denied coverage. Why then forbid similar treatment of someone who has a genetic predisposition to the same illness? Most Americans with health insurance are covered through group rated plans in which no individual risk assessment is carried out. However, the question whether to prohibit genetic discrimination is germane to assessing whether protective legislation is warranted for those who buy individual health insurance policies as well as to the life, disability and long term care insurance markets in which individual underwriting is commonplace.

One might think that distinguishing between the sick and healthy in insurance is "fair," while distinguishing between two healthy persons, only one of whom carries a genetic mutation predisposing him to disease, is not. While the sick person is already sick and will therefore surely need to make a claim against the insurance carrier, it is uncertain whether the person with the genetic predisposition will need to make a similar claim. But of course the person who is already sick will not necessarily need healthcare services. She could be hit by a bus and killed on the first day of the policy period. Moreover, in the case of some genetic diseases-albeit a small number of them-the person with the specific genetic mutation is certain to develop the predicted illness so long as she does not die of something else first. ${ }^{24}$ Whenever individual underwriting is employed, the insurer makes a prediction about the likelihood that a given insured will make a claim for reimbursement during the policy period. The difference between the person who is already sick and the person who may become sick is a difference in degree, not a difference in kind.

In this sense, genetic information is like other information that insurers routinely use in setting individually-based rates. It predicts the likelihood that a given person will draw from the insurance pool during the policy period. While information provided by the new genetic science may turn out to be a better predictor of future health, it will never be perfectly predictive. Intervening events, such as accidents, are always possible. Moreover, the impact of environmental factors upon genetic predispositions is likely to leave a substantial amount of uncertainty. How much predictive capacity genetic understanding will provide is a matter of dispute, but the point to stress here is this: genetics offers better predicitive ability but not perfect predictive ability. Although the above discussion focuses on insurance, the question

24 Geneticists use the term "penetrance" to describe this characteristic of a genetic disease. Richard R. Sharp, The Evolution of Predictive Genetic Testing: Deciphering Gene-Environment Interactions, 41 JURIMETRICS J. 145, 148 (2001). If a genetic mutation is 100 percent penetrant, then all who carry that mutation will develop the disease if they live long enough to do so. NORMAN V. RothWELl, Understanding Genetics: A MOleCular APPROACH 63 (1993). Huntington's chorea is an example of a genetic disease that is nearly 100 percent penetrant. $I d$. 
of whether genetic discrimination is different, morally speaking, from discrimination on the basis of health or illness can be raised in other contexts as well. Thus far, employment discrimination is the other area that has attracted significant attention. ${ }^{25}$ Here too, one must ask whether genetic discrimination in employment ought to be specifically forbidden.

Although the insurance and employment contexts are not the only ones in which genetic discrimination may occur, they are likely to remain the most important. The family context may become significant as well. In a child custody dispute, for example, a judge could conclude that placing the child with one parent is in the child's best interest because the other parent carries a genetic predisposition to early onset Alzheimer's disease. Perhaps prospective adoptive parents will be rejected because one parent carries the gene that causes Huntington's disease. Alternatively, prospective adoptive parents may demand that their potential child undergo genetic testing before finalizing an adoption. ${ }^{26}$ Lastly, parents who know they carry a mutation for a serious genetic disease may choose to use genetic testing to avoid carrying a child with that disease to term. ${ }^{27}$ Should discrimination on the basis of genetic factors be prohibited in these contexts?

\section{A. FAMILIAR ARGUMENTS}

This section will briefly review the arguments for genetic exceptionalism ${ }^{28}$ that justify legislation specifically targeting genetic discrimination. In most instances, these arguments are unconvincing, often for reasons that have been well-articulated by others. In order to add to this dialogue in a way that picks up where others have left off, the arguments will be discussed only briefly. The reason to discuss them is twofold. First, this review will give the reader a feel for the arguments which have already been advanced in support of legislation prohibiting genetic discrimination.

25 See supra note 3 and accompanying text.

26 The American Society of Human Genetics (ASHG), together with the American College of Medical Genetics (ACMG), report that there is anecdotal evidence that prospective adoptive parents and adoption agencies are requesting "a wider range of genetic tests before, during, or immediately after the adoption process." ASHG/ACMG Statement, Genetic Testing in Adoption, 66 AM. J. HUM. GENETICS 761, $761(2000)$. In response, the two groups have issued proposed guidelines to govern when genetic tests are performed on newborns and children during the adoption process. Id. In brief, the ASHG and ACMG:

support genetic testing in the adoption process if it is (1) consistent with preventive and diagnostic tests performed on all children of a similar age, (2) generally limited to testing for medical conditions that manifest themselves during childhood or for which preventive measures or therapies may be undertaken during childhood, and (3) not used Id. at 766 .

to detect genetic variations within the normal range.

27 Parents can avoid the birth of a child with certain genetic abnormalities in two ways. The first method combines genetic testing with selective abortion. See Cynthia Powell, The Current State of Prenatal Genetic Testing in the United States, in PRENATAL Testing, supra note 10, at 47-48. The pregnant woman would undergo amniocentesis at approximately sixteen to eighteen weeks gestation to test the developing fetus for specific genetic abnormalities. Id. The second method, called "preimplantation genetic diagnosis," uses in-vitro fertilization. See Jason Christopher Roberts, Customizing Conception: A Survey of Preimplantation Genetic Diagnosis and the Resulting Social, Ethical, and Legal Dilemmas, 2002 DUKE L \& TECH. REV. 12, 12 (2002). The fertilized embryos are then tested for the genetic abnormality and only ones that are free of the relevant mutation are transferred to the womb of the mother. Id. There are variations on these two methods but these two procedures capture most of the ways that genetic testing is used in the prenatal context.

28 Coined by Thomas H. Murray, the term "genetic exceptionalism" refers to the view that genetic information is different from other health information in ways that warrant different treatment. Murray, supra note 12, at 61 . 
Second, this Article builds on these arguments by revealing an argument that lies under the surface of much commentary and by developing and drawing out the complexities and difficulties of one of these familiar arguments. To articulate what is new requires briefly reviewing the points that have been made before.

\section{Genetic Discrimination Is Irrational}

Some supporters of special legislation argue that prohibiting genetic discrimination is necessary because such discrimination is irrational. ${ }^{29}$ First, it is important to clearly define "irrational" in this context. The concept of irrational discrimination is most often used in connection with insurance. Loosely, irrational discrimination in insurance refers to instances when insurers charge higher than normal rates to a group of persons who are not in fact more likely than average to make claims for reimbursement from the insurer. Rational discrimination, by contrast, distinguishes between groups in a way that reflects the real risk of loss each group poses. ${ }^{30}$ More precisely, discrimination is irrational if the prices charged by the insurer do not reflect the actual risk of loss each group poses as well as the cost to the insurer of distinguishing between the groups. Clearly defined, it is unclear what is morally important about discrimination being rational. Irrational discrimination is simply synonymous with bad business. To see this point, consider an example from outside of the insurance context. Law firms often select which law graduates to hire based on their grades in the hopes that grades are predictive of legal ability. If grades are not a good predictor of legal ability, then this form of discrimination by law firms is not rational. Would this irrationality make it morally troubling, however? It is entirely plausible that reviewing writing samples of students would provide a more accurate measure of which students are likely to become good lawyers. Law firms may be reluctant to use this screening method until they have narrowed the field somewhat because it is costly to review samples of student writing. The fact that firms may reject the student writing method (on the grounds of cost) emphasizes the fact that rational discrimination is simply a matter of assessing the efficiency of a proxy from the perspective of the entity employing it. It is hard to see the moral pull of this criterion.

Even so, is genetic discrimination irrational? While it is true that many people who carry a gene which predisposes them to a particular illness will not in fact become sick, it is also true that such a person is more likely than average to develop that illness, thereby making discrimination, were it to occur, rational. Moreover, the probabilistic nature of genetic information is no different from other information about a person's future health used by insurers to set rates. Not all smokers develop lung cancer. But because smokers are more likely than average to develop lung cancer, charging smokers higher health insurance rates is rational.

Supporters of protective legislation may argue that genetic information can be more complex and less predictive of future health or illness than smoking is of cancer. While this is accurate in the case of some genetic information, other genetic

29 Larry Gostin, Genetic Discrimination: The Use of Genetically Based Diagnostic and Prognostic Tests by Employers and Insurers, 17 AM. J.L. \& MED. 109, 113-15 (1991) (arguing that discrimination on the basis of genetic information is likely to be irrational because the degree of uncertainty surrounding how predictive of future illness a genetic mutation may be); Greely, supra note 13, at 1500 (offering the opportunity "to protect those people who are at risk for irrational and ill-informed genetic discrimination" as one reason to support legislation prohibiting genetic discrimination in health insurance).

30 Kenneth S. Abraham, Distributing Risk: insurance, Legal Theory, and Public POLICY 93 (1986). 
information is highly predictive. The term used by geneticists is "penetrance." The "penetrance" of a gene mutation tells us the likelihood that a person with the mutation will develop the disease over the course of his life. If a gene is seventyfive percent penetrant, then seventy-five percent of those who carry the gene mutation will develop the illness. ${ }^{31}$ Sometimes then genetic discrimination may be rational when the genetic mutation at issue is highly penetrant and sometimes it will be irrational when the genetic mutation is not highly penetrant. So far, the percentage of highly penetrant mutations among those scientists have identified is fairly significant because the fact that these diseases are strongly genetic has been fairly obvious for a long time. As scientists learn about the genetic bases for more diseases, however, these highly penetrant mutations are likely to become rarer. ${ }^{32}$

Where genetic mutations are not highly penetrant, genetic discrimination may be irrational. But will it occur? In other words, is it a problem that requires a legislative solution? First, it is important to note that the insurance statutes of all states already require that insurance rates be grounded in actuarial data; state law generally requires that insurance rates be rational. ${ }^{33}$ In employment law, by contrast, there is no general requirement of rational behavior. If an employer wants to discriminate irrationally by hiring only brown-eyed applicants for example, such

31 As Henry Greely and others have pointed out, while a small number of genetic mutations are highly penetrant, the scientific community knew of their penetrance well before the recent boom in genetic knowledge. Their high penetrance made them readily observable in family medical histories before scientists were to identify the specific gene mutation responsible. Therefore, what scientists are likely to discover in the future will be cases where the genetic component of the disease is much less significant. Greely, supra note 13, at 1487 (explaining that "the logic of the discovery process means that the strong associations [between gene mutations and disease] are likely to be rare; the less-rare associations are likely to be weak").

$32 \quad I d$.

33 The most common means of state regulation of actuarially supported insurance rates are "standard valuation laws," under which all insurers must submit to the state insurance commissioner actuarial data supporting their insurance premiums. For example, the State of Alabama's Insurance Code requires that:

Every life insurer doing business in this state shall annually submit the opinion of a qualified actuary as to whether the reserves and related actuarial items held in support of the policies and contracts specified by the commissioner by regulation are computed appropriately, are based on assumptions which satisfy contractual provisions, are consistent with prior reported amounts, and comply with applicable laws of this state. The commissioner, by regulation, shall define the specifics of this opinion and add any other items deemed to be necessary to its scope.

Ala. CODE $\S 27-36-7$ (1986); see also ALASKa Stat. $\S 21.18 .110$ (2002); ARK. CODE ANN. $\S \S 23-$ 84-101 to 23-84-113 (Lexis 1999); CAL. INS. CODE $\$ 10489.1-10489.10$ (West 1988 \& Supp. 2003); ConN. Gen. STAT. ANN. $§ 38$ a-78 (West 2000); Del. Code AnN. tit. 18, $\S 1113$ (1999); D.C. CodE ANN. §31-4701 (2001); FLA. STAT. ANN. § 625.121 (West 1996 \& Supp. 2003); GA. CODE ANN. § 33-10-13 (2000); HAw. REv. STAT. ANN. \$ 431:5-307 (Michie 2001); IDAHO CODE $\$ 41-612$ (Michie 1998 \& Supp. 2002); 215 ILL. COMP. STAT. ANN. 5/223 (2000); IOWA CODE ANN. $\$ 508.36$ (West 1998 \& Supp. 2002); Kan. STAT. ANN. $\$ 40-409$ (2001); KY. REV. STAT. ANN. $\$ 304.6-120$ (Michie 1997); ME. REV. STAT. ANN. tit. 24-A, $\S \S 951-958-A$ (2000); MD. CODE ANN., INS. $\$ \S ~ 5-301-5-312$ (1997 \& Supp. 2002); MINN. STAT. ANN. § 61 A.25 (West 1996 \& Supp. 2003); Miss. COdE ANN. $\S$ 83-7-23 (1999); MONT. CODE ANN. \$§ 33-2-521-33-2-529 (2000); NEV. REV. STAT. ANN. \$ 688A.325 (2001); N.H. REv. STAT. ANN. \$ 410 (1998); N.J. STAT. ANN. \& 17:19-8 (West $2001 \&$ Supp. 2002); N.M. STAT. ANN. § 59A-8-5 (Michie 2000); N.C. GEN. STAT. $§ 58-58-50$ (2001); N.D. CENT. CODE $\S \S 26.1-35-01$ to 26.1-35-10 (2001); OKLA. STAT. ANN. tit. 36, § 1510 (West 2002); OR. REV. STAT. $\S 733.300$ to 733.322 (2001); R.I. GEN. LAWS $\S$ 27-4.5-1 to 27-4.5-12 (2002); TENN. CODE ANN. §56-1-403 (2000); TEX. INS. CODE ANN. $\$ 3.28$ (Vernon 2002); UTAH CODE ANN. $\S$ 31 A-17-501 to 31A-17-513 (2002); VT. STAT. ANN. tit. 8, $\$ 3781-3789$ (2001); WASH. REV. CODE ANN. $\$ 48.74$ (West 1999); W. VA. CODE ANN. § 33-7-9 (Michie 2000 \& Supp. 2002); WIS. STAT. ANN. $§ 623.06$ (West 1995 \& Supp. 2002). 
irrational discrimination by itself is not prohibited. It is only prohibited when the particular irrationality is of a special sort, and then not because it is irrational. Race, sex and disability discrimination, for example, are largely prohibited whether they are rational or irrational. ${ }^{34}$

Second, why think that irrational discrimination will occur at all? Irrational discrimination is, by definition, irrational and therefore bad business. Those who believe the market is mostly rational should be confident that irrational discrimination will not be a long-term problem. ${ }^{35}$ But perhaps the insurance and employment markets are not as rational as the economist likes to suppose. So far, this worry does not appear to be warranted. Despite the fears of genetic scientists and people with genetic diseases, there is very little evidence of genetic discrimination in insurance or employment. ${ }^{36}$ But that may change. Genetics is still not well understood by insurers and employers. As genetics makes its way into common discourse, discrimination could become more common. Moreover, because insurers and employers may have only an incomplete and unsophisticated understanding of genetics, irrational discrimination may occur. While this is conjecture, the important question to ask is, if irrational genetic discrimination were to become a bigger problem than it is now, would that be a reason to prohibit it?

Three reasons argue against prohibition. First, the law will be over-inclusive if its aim is to ban only irrational genetic discrimination because some genetic discrimination is rational. Second, current law already bans irrational discrimination in insurance, though these laws are surely less potent than a law specifically banning genetic discrimination in insurance. Third, and most importantly, it is not at all clear why being subject to irrational discrimination is a significant moral harm that requires remediation. Rational discrimination is simply the making of distinctions

34 Compare Frontiero v. Richardson, 411 U.S. 677, 690-91 (1973) (striking down a federal law that provided male married armed service members an automatic dependency allowance, but which required female married members to prove the dependency of their spouses) with Reed $v$. Reed, 404 U.S. 71, 76 (1971) (striking down an Idaho law that gave a preference to men over women as estate administrators on the ground that it was "arbitrary").

35 Richard Epstein is the most forceful advocate of this position. See RICHARD EPSTEIN, ForbidDEn Grounds: THE CASE AGainst EMployment Discrimination LAWS 42 (1992) (arguing that "there are natural curbs against irrational contracting behavior" and thus that "the legal system normally has no need to superintend the wisdom of bargains"); see also Epstein, supra note 6.

36 Greely, supra note 13, at 1483 (contending that "[g]enetic discrimination is a much greater threat in people's fears than it is in reality, today or in the foreseeable future, for both scientific and social reasons"); Rothstein \& Anderlik, supra note 7, at 357 (pointing out that "[t]o date, the evidence of genetic discrimination has been anecdotal (Billings et al. 1992; Geller et al. 1996) or derived from studies with methodological weaknesses such as reliance on self-report (Lapham et al. 1996)" and that, therefore, "a recent study combining in-person interviews with health insurers and a direct market test has attracted considerable attention (Hall and Rich 2000)" because it found that "a person with a serious genetic condition but asymptomatic for disease would have little or no difficulty obtaining individual health insurance under current market conditions"). But see E. Virginia Lapham et al., Genetic Discrimination: Perspectives of Consumers, 274 SCIENCE 621, 623 (1996) (finding that " $43 \%$ of the respondents reported that they or members of their family have experienced genetic discrimination in one or more of the three areas" of health insurance, life insurance and employment). This study is based on the typc of statistical self-reporting that Rothstein and Anderlik critique. See Rothstein \& Anderlik, supra note 7, at 357. Lapham and her co-authors define genetic discrimination to include cases in which the individual discriminated against is already symptomatic for the disease, whereas Hall and Rich looked for evidence of cases in which discrimination occurred when the person has a genetic predisposition but no manifest disease. Compare E. Virginia Lapham et al., Genetic Discrimination: Perspectives of Consumers, 274 SCIENCE 621 (1996) with Mark A. Hall \& Stephen S. Rich, The Impact on Genetic Discrimination of Laws Restricting Health Insurers' Use of Genetic Information, 66 AM. J. HEALTH GENETICS 293 (2000); see also infra note 70-75. This definitional difference may, in part, explain the wide disparity of results. 
that are economically sensible to make from the perspective of the insurer, employer or other actor who draws such distinctions. A bad business judgment, without more, does not constitute a moral wrong to the person disadvantaged by that judgment. The fact that some genetic discrimination is irrational, therefore, does not provide a reason to ban genetic discrimination.

\section{Genes Are Beyond Individual Control}

A common argument for singling out some attributes for protection from discrimination is that the traits in question are "immutable" ${ }^{\text {"37 }}$ or beyond individual control. ${ }^{38}$ The moral intuition underlying this argument is that a person ought to be granted or denied a benefit on the basis of what she does, not who she is. This conception of merit is subject to contention in its own right. ${ }^{39}$ Its virtues and complexities will not be examined here, however. For now, this Article argues that immutability fails as a reason to prohibit genetic discrimination for two reasons. First, this principle is not one that is adopted in our current laws. In fact, most goods are distributed according to quite different principles. The basketball player who earns millions of dollars for his performance earns that money only partially in recognition of his effort. His height - a trait beyond his control-and his natural talent also play a role in making him a skilled player. Moreover, while many of the traits on which discrimination is prohibited are immutable (or mutable only at great effort), traits such as race or sex for example, others are accorded special protection, even if they are in fact highly mutable, such as religion.

Second, while the idea that one ought to be held responsible only for those traits over which one has control has important moral appeal and is surely at the heart of much of our criminal law, it is far more complex conceptually than it initially appears. The idea that a smoker ought to pay more for health insurance than a nonsmoker seems morally appealing because the smoker, in choosing to smoke, is thereby at least partially responsible for the fact that she is more likely than the nonsmoker to become sick. However, even that example is problematic because of the additive quality of nicotine and the fact that scientists are beginning to learn that qualities outside of individual control influence the degree to which each smoker in fact endangers his or her health by smoking. As scientists learn more about genetic predispositions to disease, they discover that our bodies make demands on us unevenly. For example, some people can eat high fat diets with little health risk while others must maintain extremely prudent low fat diets in order to have similar risks of disease. While dietary choices are within individual control, the genetic predispositions that make them necessary are not. If we say that the second person is responsible for her poor health if she does not follow the prudent diet, but that the first person is free to indulge, then we in fact hold the second person responsible for

37 See, e.g., ERwin Chemerinsky. Constitutional LaW: Principles \& Policies 551 (1997) (explaining that one of the three central reasons that the Supreme Court scrutinizes the use of some legal classifications closely is the fact that the trait at issue is immutable). As Chemerinsky articulates the moral intuition behind this strand of law, "[i]t is unfair to discriminate against people for a characteristic that is acquired at birth and cannot be changed." Id.

38 See Gostin, supra note 29, at 110-11 (arguing that because genetic conditions are "neither subject to the person's control, nor the result of willful behavior," genetic discrimination ought to be prohibited).

39 For an interesting examination of the complexities of the merit principle, see Judith Lichtenberg \& David Luban, The Merits of Merit, 17 REP. FROM INST. FOR PHIL. \& PUB. POL'Y 21 (1997). 
factors beyond his control-the fact that his genetic make-up demands an especially low fat diet. ${ }^{40}$

\section{A Small Number of People Are Especially Burdened by Genetic Disease}

A related argument for protection from genetic discrimination is based on the fact that genetic predisposition to disease is distributed quite unequally. While most of us may turn out to have roughly equivalent risk profiles-somewhat higher than average risk of $\mathrm{X}$, combined with lower than average risk of $\mathrm{Y}$-there are likely to be smaller groups of people who are extremely lucky or extremely unlucky in terms of their genetic make-up. For the few extremely unlucky, a social policy that permits discrimination on that basis would seem to cruelly compound their misfortune. Professor Greely makes this point in support of limited protection from genetic discrimination in health insurance and employment. ${ }^{41}$

While this argument may seem persuasive, it does not explain why those whose genetic make-up predisposes them to illness deserve special solicitation that those whose poor health has already manifested do not. After all, the argument that it would be especially cruel to compound the misery of the unlucky is stronger still with regard to those who have already become sick. Whatever responsibility our community has to provide basic healthcare to those who are especially likely to become ill surely also extends to those who are already sick.

Greely offers three arguments to support his view without explicitly addressing the question of how these arguments differentiate genetic discrimination from health status discrimination. He reasons (1) that "employment and health insurance are important parts of life in contemporary America;" (2) that "we can afford [it];" and (3) that providing such protection "should have only minor costs to the economy but major benefits for those few people whose jobs or health insurance would be saved." ${ }^{, 42}$ The second two points relate to why special protection for genetic discrimination is warranted. Protecting those with manifest illness from the same sorts of employment and health insurance discrimination would presumably be more expensive, perhaps putting pressure on our ability to afford such protection and disrupting the economy in greater ways. However, the benefits to those whose jobs or health insurance would be saved would also be greater. Why this is the point at which the cost simply becomes too great is a claim that requires more discussion to be persuasive. Without it, there is no clear reason to include some who are unlucky with regard to health in the important goods of society (for Greely is surely right that health insurance and employment are extremely important) but not others.

\section{Genetic Traits Are Shared with Racial or Ethnic Groups}

One reason the genetically unlucky may deserve special protections that those who are merely sick do not is that particular disease-causing genetic mutations may especially affect identifiable racial or ethnic groups. For example, sickle-cell trait generally affects Africans and African-Americans, ${ }^{43}$ and two mutations associated

40 Cf. Deborah S. Hellman, Is Actuarially Fair Insurance Rating Actually Fair?: A Case Study In Insuring Battered Women, 32 HARV. C.R.-C.L. L. REV. 355, 364-69 (1997) (arguing the ability to control one's own health is not in itself enough to justify responsibility for it).

41 Greely, supra note 13, at 1500.

$42 \mathrm{ld}$.

43 Lemmens, supra note 5, at 373 (reporting that "in the U.S., from $8 \%$ to $10 \%$ of AfricanAmericans are carriers of the sickle-cell trait, and 1 in 400 to 600 has sickle-cell anaemia"). 
with breast cancer are more common among Ashkenazi Jews. ${ }^{44}$ When the group affected is one which has already been stigmatized in our society, there is a risk of further entrenching negative attitudes and of over-reacting to the significance of the association. $^{45}$

Though important, these associations alone do not justify a ban on genetic discrimination. First, while the associations between some genetic diseases and stigmatized racial or ethics groups seem significant today, this significance will probably wane. The nature of genetic research makes it easier to identify genetic mutations among relatively homogeneous and relatively small ethnic groups. ${ }^{46}$ But, as scientists' ability to identify the function of genes grows, the relevance of these small populations for study will diminish. It is probably not the case that Ashkenazi Jews, for instance, have more disease predisposing genes than other ethnic groups. It just seems so now because their group is easier to study.

Moreover, there are many disease-causing genetic mutations that are not in fact more prevalent among already stigmatized racial or ethnic populations. Huntington's disease and early onset Alzheimer's disease are two prominent and particularly devastating examples. In addition, as Professor Trudo Lemmens argues, there are similar associations between non-genetic diseases and racial or ethnic groups. For example, there is a "lower incidence of high cholesterol levels among certain ethnic groups" and "HIV/AIDS is more prevalent among gays and intravenous drug users and specific ethnic communities."47 To ban genetic discrimination because of the risk of further stigmatizing racial and ethnic groups that are already subordinated in our society would be to enact a law that is quite dramatically both over- and under-inclusive.

\section{Stigma}

Some supporters of protective legislation argue that it is necessary because the genetic predisposition to disease is itself stigmatizing. Like the concern that racial prejudice creates a color hierarchy in our society, one might worry about a genetic hierarchy. For example, those whose genes especially predispose them to disease may be viewed as less desirable as customers for insurance, as employees or as marriage partners. The argument contends that because genetic predisposition to disease is stigmatizing, discrimination on this basis ought to be prohibited.

While superficially appealing, this argument is underdeveloped. First, in order to work as an argument for special legislation forbidding genetic discrimination as distinct from discrimination on the basis of health status, one must claim not just that having a genetic predisposition to disease is stigmatizing, but that it is more

44 Id. (citing S.V. Hodgson et al., Risk Factors for Detecting Germline BRCAI and BRCA2 Founder Mutations in Ashkenazi Jewish Women with Breast or Ovarian Cancer, 36 J. MED. GENETICS 369 (1999)).

45 See Janet L. Dolgin, Personhood, Discrimination and the New Genetics, 66 Brook. L. REV. 755, 786-87 (2000-01) (arguing that "[e]mployers, insurers, and others may arrive at assumptions about an individual's genome from information regarding the genome of the individual's ethnic group" and that "[s]uch discrimination may be especially harmful when aimed at individuals belonging to groups that have historically been singled out for racist treatment on the basis of somatic characteristics"); Gostin, supra note 29, at 111 (claiming that the "fact that genetic diseases are sometimes closely associated with discrete ethnic or racial groups such as African Americans, Ashkenazi Jews or Armenians compounds the potential for invidious discrimination").

46 For that reason, Ashkenazi Jews, for example, provide a fertile population for study. Dolgin, supra note 45 , at 789-90.

47 Lemmens, supra note 5, at 374. 
stigmatizing than having an already manifested illness. Second, and more importantly, the meaning of "stigma" is not clear in the way this argument is generally presented. ${ }^{48}$ It is thus hard to evaluate the argument's strength. There are two reasonable reconstructions of what those commentators who object to genetic discrimination on the basis of stigma may have in mind. First, stigma may refer to the effect on the persons with the genetic condition. That is, genetic discrimination is wrong because it causes harm. Second, stigma may refer to what the policy of genetic discrimination expresses. According to this interpretation, genetic discrimination is wrong because of the meaning expressed in distinguishing people on this basis. This expressivist argument is important and is implicit in much of the critique of genetic discrimination. It has not, however, been carefully articulated and evaluated. I will take up that task below. If stigma refers to the effect on the person, one still must ask what harm in particular is at issue and why this harm makes such discrimination wrong. If a person is denied a job or insurance coverage because of the genetic traits she carries, the harm suffered by the loss of the job or insurance is not a stigmatic harm. Moreover, it is surely not a harm that distinguishes genetic discrimination from discrimination on the basis of health. Perhaps stigmatic harm refers to the psychological effect on the person denied the good because of her genetic traits. This way of understanding stigma is familar from arguments made about what makes race discrimination wrong. Brown v. Board of Education ${ }^{49}$ argued, after all, that racial segregation of black school children was unconstitutional because of the effect on the "hearts and minds" of the children.

As I have argued elsewhere, this conception of what makes discrimination wrong is flawed. ${ }^{51}$ If harm to the person subject to discrimination were a necessary component of wrongful discrimination, then racial segregation of facilities for those in a permanent vegetative state would not be wrongful because such persons are incapable of suffering psychological or emotional hurt. As this conclusion seems untenable, the claim that wrongful discrimination requires that those affected feel stigmatized fails.

Moreover, stigma seems to connote something bigger or more systemic than simply the psychological effect on the individuals at issue. The idea of stigma carries with it the idea of a class or caste-like distinction between groups of people. Perhaps what is wrong with genetic discrimination, and distinguishes it from discrimination on the basis of health, is that it threatens to create a genetic underclass. This fear and accompanying argument for legislation prohibiting genetic discrimination appears in several places in the literature, but is most forcefully articulated by Susan Wolf. ${ }^{52}$

\section{Geneticism}

Professor Susan Wolf argues that the tendency to focus on genetics and to use information about genetics to subordinate people is best termed "geneticism"-a

48 See, e.g., Lemmens, supra note 5, at 411 (arguing for some regulation of genetic discrimination in Canada on the grounds that "[t]here can be circumstances in which genetic discrimination has such a symbolic, stigmatizing character, that allowing it to be used for insurance purposes would be considered inappropriate per $s e$ " (emphasis added)). Lemmens' treatment of symbolic as synonymous with stigmatizing implies that he is characterizing the idea of stigma as expressive harm. See id. This implication, however, is not clear.

49347 U.S. 483 (1954).

$50 \quad$ Id. at 494.

51 Hellman, Expressive Dimension, stupra note 9, at 10

52 See infra notes 53-58 and accompanying text. 
label she uses to call attention to a deeply ingrained mindset and set of structural practices. $^{53}$ Wolf does not in fact support the enactment of laws prohibiting genetic discrimination because she believes that the anti-discrimination paradigm is inapt and will result in more harm than good. Her objection is grounded in critiques of the anti-discrimination approach as applied to problems of racism and sexism. She believes that "clinging to 'genetic discrimination' ... does damage by creating a false genetic 'norm,' frustrating structural reform, obscuring the deep psychological roots of genetic stereotyping and prejudice, and isolating genetic from other harms." $" 54$ Consequently, she argues for a conception of the issue as something deeper, more entrenched, and more problematic, such that change of a systemic nature is required. ${ }^{55}$

Thus, while Wolf does not support laws prohibiting genetic discrimination, her approach does support the idea of genetic exceptionalism. Although she does not argue that genetic discrimination is meaningfully different than discrimination on the basis of health status, Wolf's whole approach seems to endorse the view that geneticism is importantly different from healthism, to use her terminology. For that reason, I consider her approach here.

How does Wolf argue that geneticism is different? She focuses on demonstrating the harms of an anti-discrimination approach rather than on demonstrating that geneticism pervades society. She takes this to be obvious, and merely calls our attention to "the eagerness to draw genetic conclusions, the search for supposedly deviant genes, and the conviction that such genes actually deserve disadvantage" ${ }^{\prime 56}$ that she terms geneticism. What is not clear from Wolf's critique is how one is to know that certain inequalities in the world, such as inequalities that track genetic predispositions to disease, are morally problematic while others are not. Surely, the mere fact that there is equality along some dimensions in a society does not make that society unjust. It is fair to assume that we are all committed to the idea that each person is entitled to equal concern and respect. ${ }^{57}$ Beyond that, there is much debate. For example, traditionally those on the political left stress the importance of lessening social and economic inequalities, while those on the political right emphasize the importance of equality of negative liberties like speech, assembly and economic activity. The important question that Wolf fails to address is how one is to know that the particular inequalities she identifies by her term geneticism are morally problematic. A theoretical link is missing from Wolf's argument. She needs to explain why the inequality she highlights is one that matters morally. In order to do so, Wolf needs to make use of a general theory of when discrimination is wrong, a task she avoids because she shuns the anti-discrimination paradigm. Without it, her approach is unable to do more than call our attention to the fact that genetic differences are salient in our society in a way that can work to subordinate people. As Professor Amartya Sen insightfully emphasizes, since

53 Wolf, supra note 7 , at 350 .

$54 \quad I d$. at 350.

55 Id. (arguing for a "reinterpretation of 'genetic discrimination' as something bigger, the use of genetic notions to create and reinforce power relationships in which some dominate and others are subordinated").

$56 \quad$ Id. at 347.

57 Ronald Dworkin offers this principle of equal concern as the moral principle underlying the Equal Protection Clause. Ronald Dworkin, In Defense of Equality, 1 SoC. PHIL. \& POL'Y 24,24 (1983) (positing that equal protection requires that "the interests of the members of the community matter, and matter equally"). I build on Dworkin's principle in my article on the expressive dimension of Equal Protection. Hellman, Expressive Dimension, supra note 9, at 7-8. 
equality among people across all dimensions of life is impossible, moral theories differentiate themselves by articulating what sort of equality is morally significant. ${ }^{58}$ To merely note a particular inequality - people with trait $\mathrm{X}$ have less of $\mathrm{Y}$-is not enough. One must also explain why this sort of inequality is one that is morally problematic.

In my view, one can only determine whether a given inequality violates the equal concern mandate by looking at the social meaning of that inequality in the particular society. In other words, a policy that discriminates is wrong if the policy expresses that people are not of equal moral worth. Clearly this is a theory that requires some elaboration. While a detailed argument for the expressive conception of wrongful discrimination will not be presented in this Article, ${ }^{59}$ below I will examine how the argument can be developed in the context of genetic discrimination. It is important to do so because this argument is implicit in much of the critique of genetic discrimination. Before examining this expressivist argument in some detail, however, I will discuss one more familiar argument for legislation prohibiting genetic discrimination.

\section{The Health Benefits of the Human Genome Project}

The last argument in support of legislation prohibiting genetic discrimination that I will consider here emphasizes the tremendous health-promoting potential of advances in understanding human genetics and the genetic basis for disease. Supporters of protective legislation argue that fears of genetic discrimination may thwart the promise of genetic science in two ways. First, people who fear discrimination may be reluctant to take genetic tests that could identify their risk for particular diseases. If there are therapies or other interventions that may benefit them, this fear may frustrate efforts to improve health through genetic understanding. ${ }^{60}$ Second, if people are fearful of discrimination, they may be reluctant to participate in research that includes genetic testing. ${ }^{61}$ Because scientists are just beginning to understand how genetic traits influence disease, this research is critically important to achieving substantial health benefits from the Human Genome Project.

These are important issues to consider. An understanding of genetic diseases stands to benefit us all. In addition, this argument provides an answer to the question with which we began this inquiry: in what way is genetic discrimination morally different from discrimination on the basis of health such that it warrants special protection? If fears of genetic discrimination will frustrate the healthenhancing potential of advances in genetic science, then this provides a reason to

58 See generally AMARTYA SEN, INEQUaltTy REEXAMINED (1992).

59 Cf. Hellman, Expressive Dimension, supra note 9.

60 Several commentators offer this argument in support of legislation prohibiting genetic discrimination. See, e.g., Gostin, supra note 29, at 113 (emphasizing that "if fear of discrimination deters people from genetic diagnosis and prognosis, renders them less willing to confide in physicians and genetic counselors, and makes them more concerned with the loss of a job or insurance than with care and treatment, the benefits of genetic data collection will not be fully achieved"); Greely, supra note 13, at 1501 (arguing that legislation is warranted in part because "people who are afraid of genetic discrimination are afraid to take genetic tests that offer the possibility of improving their health").

61 Greely, supra note 13, at 1501 (stressing the fact that reducing people's fears of discrimination is important because "research in human genetics has enormous potential for alleviating human suffering"); Lemmens, supra note 5, at 364 (arguing that studies "have indicated that women at risk for breast cancer because of family history often refuse to undergo testing out of fear of the impact of testing on insurability"). 
specially protect people from genetic discrimination. However, this simple argument ought not to end the inquiry. There are several questions, both empirical and philosophical, that require attention before one can conclude that enhancing health provides a sufficient reason to support protective legislation. This more complete analysis, which has thus far been missing from the literature, will be examined below. ${ }^{62}$

\section{B. NEW ARGUMENTS}

This brief review of the most familiar arguments for legislation prohibiting genetic discrimination lays the groundwork for the contributions of this Article. This section focuses on two arguments for genetic exceptionalism. First, I will look closely at the argument that genetic discrimination is different because fear of genetic discrimination will thwart the tremendous health-enhancing potential of the Human Genome Project. Second, I will examine the argument that genetic discrimination is meaningfully different from discrimination on the basis of health and therefore necessitates protective legislation because of what the practice of genetic discrimination expresses. Each of these arguments is promising. Below, I present a detailed analysis of the strengths of each in a way that will, I hope, advance the discussion of whether genetic discrimination really is different.

\section{The Policy Argument: Promoting Health}

The first argument to carefully consider emphasizes the consequences of policy choices and argues that legislation prohibiting genetic discrimination ought to be adopted in order to ensure the realization of the tremendous health enhancing potential of the Human Genome Project. Rather than claiming that the rights of people with genetic conditions will be violated if legislation is not adopted, this argument contends that laws forbidding genetic discrimination will serve the general social welfare in the form of medical advances. As such, the persuasiveness of this argument depends on the accuracy of significant empirical claims.

The argument is not new and was therefore outlined briefly above. It is, however, an important argument, the complexities and implications of which have not yet been adequately addressed. In order to do that here, let me first restate the claim. The scientific advances in understanding the genetic basis for disease have enormous potential to improve health. Understanding individual predispositions to disease may allow medical advice to be individually tailored, both for prevention and for treatment. ${ }^{63}$ For example, some people may be advised to change their diets or to be screened for disease more frequently than is ordinarily recommended. If a person develops the disease nonetheless, more individualized treatment recommendations may be available. Most exciting of all, a greater understanding of genetics may allow doctors to treat people with strong predispositions to serious illness prophylactically so that the illness itself never develops.

Genetic discrimination is a problem, then, because it may get in the way of each of these beneficial developments. If people fear genetic discrimination, they may be reluctant to be tested for genetic conditions. If so, achievement of the health

62 See infra notes 63-98 and accompanying text.

63 Whether individuals will in fact change their behavior in response to genetic information is uncertain. See Theresa M. Marteau \& Caryn Lerman, Genetic Risk and Behavioural Change, 322 BRIT. MED. J. 1056, 1058 (200I) (finding that "current evidence suggests that providing people with DNA derived information about risks to their health does not increase motivation to change behaviour beyond that achieved with non-genetic information"). 
benefits described above may be thwarted in two ways. First, if people avoid testing, they may fail to partake in the therapeutic benefits that are currently available. Second, and perhaps more importantly, people who fear discrimination may decline to participate in research involving testing-research that could lead to discoveries that ultimately make pre-symptomatic treatment of genetic conditions possible. This second effect is particularly important because, at present, scientists have learned a lot about which gene mutations predispose one to certain diseases, but they have not yet been able to intervene that productively to help. One hopes that by building on current knowledge scientists will be able to discover how to advise individuals with particular genetic conditions to alter their diets or habits so as to improve health. New knowledge may even make it possible to treat incipient conditions before they develop. However, this is still a hope and promise of genetic science, not the reality. If people are unwilling to participate in research involving genetic testing because they fear genetic discrimination, scientific advances in this area may be dramatically slowed.

This argument surely sounds both plausible and significant. The argument rests on several assumptions, however-some empirical and some ethical-that require further consideration.

\section{a. Empirical Questions}

Many people considering genetic testing report that they fear genetic discrimination. ${ }^{64}$ In order for legislation forbidding genetic discrimination to be successful in removing this barrier to testing or participation in research, proposed legislation must forbid the sorts of genetic discrimination that people actually fear. For example, Greely believes that "genetics has enormous potential for alleviating human suffering" and, thus, that "reducing that fear is important" because "people who are afraid of genetic discrimination are afraid to take genetic tests that offer the possibility of improving their health" and "may be afraid to take part in genetic research that could provide important answers to major diseases." 65 For this reason, among others, Greely supports modest federal legislation forbidding genetic discrimination in health insurance and employment. ${ }^{66}$ To be effective, however, people must fear discrimination in health insurance and employment. If people also fear discrimination in life insurance or disability and long-term care insurance, for example, legislation that is limited to the healthcare and employment contexts is

64 See Lapham et al, supra note 36 , at 622 (reporting that in a study surveying the experiences of people with family histories of genetic disease that "[t]he large majority (83\%) of respondents said they would not want their insurers to know if they were tested and found to be at high risk for a genetic disorder"). In addition, Lapham and her co-authors found that "fear of genetic discrimination ... resulted in $9 \%$ of the respondents or a family member refusing to be tested for a genetic condition." Id.; but see P.B. Jacobson et al., Decision-Making about Genetic Testing Among Women at Familial Risk for Breast Cancer, 59 PSYCHOSOMATIC MED. 459, 465 (1997) (finding that "the only disadvantages perceived by a majority of women were that learning their genetic carrier status would increase their concerns about developing breast cancer and cause them to worry more about other family members who could be carriers"). Interestingly, when people with a family medical history of a particular disease are considering genetic testing, genetic discrimination may not be of foremost concern because some information about genetic risk (albeit less precise) is already present in the form of that family medical history. Therefore, other issues take precedence in the decisionmaking.

65 Greely, supra note 13, at 1501.

66 Id. at 1504 (describing the scope of legislation forbidding genetic discrimination that he favors as "limited to employment questions and to health coverage (whether through traditional health insurance, HMOs, or a self-funded employee health benefit plan)”). 
unlikely to promote health in the way that Greely hopes. Consider the case of someone contemplating entering a research study dealing with the genetic predisposition to early onset Alzheimer's disease. For this person, the availability of long-term care and disability insurance are critical issues. Because most Americans who have healthcare coverage get that coverage through large group plans that do not individually assess the risk of each covered person, protection from discrimination in health insurance is likely to be the least of this person's concerns. If so, limited legislation may do little to affect people's decision-making about whether to participate in testing or research.

People's fears of genetic discrimination may extend further still. Perhaps their central worry is that they will be unable to adopt children, or that in a custody battle they will be denied custody of the children because of their genetic condition. Also, these fears may extend to genetic discrimination in contexts that no one is likely to advocate regulating. People may fear that no one will want to marry them if they test positive for some conditions, or that mates or family members will abandon them. ${ }^{67}$ In order to argue that states or the federal government ought to adopt legislation prohibiting genetic discrimination to ensure that the health-enhancing potential of genetic science is realized, one must ascertain that the legislation will allay precisely the fears that are liable to affect decisions about testing.

It is not enough to cite studies documenting the fact that people fear genetic discrimination. One must determine in what contexts people fear genetic discrimination as well as to what degree. One must then assess whether the goal of promoting health through advances in genetic knowledge warrants legislation forbidding genetic discrimination in those areas, be it life and disability insurance, family law or personal life. Finally, if people fear the sorts of discrimination described above, but society is only willing to forbid discrimination in health insurance and employment, one must determine whether this limited protection will be enough to tip the balance for people toward a decision to participate in research or to undergo testing when it is therapeutically valuable. Otherwise, legislation forbidding discrimination in health insurance and employment will not achieve the goal of promoting participation in genetic research.

This discussion suggests that more empirical research is needed about precisely what sorts of protective legislation would indeed allay people's fears and, more importantly, affect their decisions about whether to be tested or to participate in research involving testing. Additionally, while fear of genetic discrimination in any context may indeed be part of the reason that people shun genetic testing, there are a plethora of other possible reasons. For example, there has been very little interest in testing for the genetic mutation responsible for Huntington's disease, ${ }^{68}$ a fatal, degenerative disease for which there is currently no treatment or therapy. While fears of discrimination may explain in part why some people at risk for the disease avoid testing, it is easy to imagine other explanations. Here Sophocles's oft-cited admonition taps a powerful intuition: "what misery to be wise when wisdom profits

67 See Lori B. Andrews, A Conceptual Framework for Genetic Policy: Comparing the Medical, Public Health, and Fundamental Rights Models, 79 WASH. U. L. Q. 221, 245-49 (2001) (discussing data about the actual impact of genetic testing on relationships with spouses and potential spouses).

$68 \mathrm{Id}$. at 250 (explaining that contrary to scientists' initial expectation that many people at risk for Huntington's disease would choose to be tested, in reality "fewer than fifteen percent of at-risk individuals chose to undergo the testing"). 
nothing." ${ }^{\text {"69 }}$ Until we know how important fears of genetic discrimination are, relative to other considerations, we cannot say that legislation prohibiting genetic discrimination will in fact promote the fulfillment of the promise of genetic science.

Mark Hall and Stephen Rich have begun this important research in a study in which they conducted interviews of genetic counselors and medical geneticists at major medical centers. The study assessed whether recent state laws that prohibit genetic discrimination have been successful in reducing fear of health insurance genetic discrimination and whether the laws have thereby resulted in more testing. ${ }^{70}$ Briefly, they reached the following conclusions on the basis of their study:

1. Fear of losing health insurance is the primary concern of people concerned about genetic discrimination. ${ }^{71}$

2. These fears "do not have very much actual impact on patients' final decisions about testing." 72

3. Patients may cite fear of discrimination as a reason to decline testing because "it gives them a more socially acceptable reason to decline." "73

Notably, these conclusions did not differ between states that had adopted laws forbidding genetic discrimination and states that had not. ${ }^{74}$

These conclusions suggest that the argument that one ought to prohibit genetic discrimination in order to promote health by encouraging participation in genetic testing and research may rest on shaky empirical ground. However, though the Hall and Rich study is important and provocative, it is limited. First, the study based its conclusions on the views of genetic counselors. As Hall and Rich acknowledge, some people who are deterred from testing may never make it as far as a session with a genetic counselor. ${ }^{75}$ Second, as Hall and Rich acknowledge, the study focused on genetic testing for Huntington's disease and cancer, conditions in which the test accuracy is high and there is often little treatment that has therapeutic benefit. In a different context, potential testers may well react differently. Third, the Hall and Rich study methodology centers on the counselors' and geneticists' impressions of the clients' motivations. While surely useful, these impressions may be inaccurate. Finally, it is also important to remember that this is only one study and more empirical research is necessary.

One should also examine whether the desire to promote health provides a reason to forbid genetic discrimination in a way that distinguishes genetic discrimination from discrimination on the basis of general health status. The health promotion argument in favor of legislation forbidding genetic discrimination rests on the assertion that fear of genetic discrimination keeps people from testing or research that, in turn, thwarts the health-promoting potential of genetic science. There is nothing morally special, however, about promoting health through genetics. The argument examined in this section is appealing because health is important. In order for health promotion to provide a good reason to support legislation specifically forbidding genetic discrimination, one must determine that forbidding genetic

69 SophoCles, Oedipus THE KING 28 (Anthony Burgess trans., Univ. Minn. Press 1972).

70 Mark A. Hall \& Stephen S. Rich, Genetic Privacy Laws and Patients' Fear of Discrimination by Health Insurers: The View from Genetic Counselors, 28 J. L. MED. \& ETHCS 245 (2000).

$I d$, at 249.

Id.

Id. at 251 .

ld. at 252-53.

Id. at 253 . 
discrimination would promote health more than would prohibiting discrimination on the basis of health status more generally. The discrimination on the basis of health status that is currently permitted may also undermine health because people may refrain from other non-genetic, therapeutically useful medical tests in order to avoid discrimination.

Finally, if promoting health is important, and legislation forbidding genetic discrimination is warranted as a means to that end, one must also ask whether enactment of this legislation may simultaneously work to thwart that goal. If enactment will sap political will for the passage of some form of universal healthcare or universal health insurance coverage, then legislation forbidding genetic discrimination could undermine, rather than enhance, health. While one can only speculate about this question, access to healthcare for all Americans may be so important to the goal of promoting health that this concern is worth careful consideration.

I argue above that in order for the goal of health promotion to provide a reason to enact legislation forbidding genetic discrimination, one must examine several empirical questions to determine whether enactment of such legislation will indeed achieve that result. Before moving on, it is worth considering an objection to the health promotion argument that would make these empirical questions unimportant. Professors Colin Diver and Jane Maslow Cohen argue that protecting people from the economic consequences of a testing decision by passing legislation forbidding genetic discrimination is a mistake because it will encourage more testing than ought to occur. This is a strange yet familiar "law and economics" type argument:

When a person decides not to undergo genetic testing, she is presumably deciding that her net utility would be reduced: that is, that the costs (including not only the direct costs of undergoing the testing, but also the expected adverse impact that the resulting knowledge would produce on both her economic prospects and her psychological state) outweigh the benefits (in terms of the improvement in her, and perhaps her offspring's, health that could result from ameliorative actions). By protecting individuals from adverse employment and insurance consequences, the antidiscrimination strategy eliminates two components of the economic costs of testing from the individual's cost-benefit calculus. In doing so, the government in effect encourages overconsumption of genetic testing. ${ }^{76}$

The flaw in this argument is that it assumes the very point it is attempting to show. The authors assume that the correct amount of testing is the amount that would occur if insurers and employers could discriminate on the basis of genetic information. If so, forbidding such discrimination and thereby shielding potential testers from these economic consequences will lead to "overconsumption" of testing. However, the amount of testing that would take place if discrimination were forbidden is only overconsumption if the correct amount is precisely the amount that would take place absent such protection. Missing from their argument is an explanation for why they take this amount of testing to be the baseline from which any deviation demands explanation.

A claim that a certain amount of testing is the right amount requires justification. The claim that the right amount is that amount that will promote health 
in the long run by providing enough people willing to undergo testing to allow productive research to continue is such a reason. Alternatively, one might argue that the right amount of testing is the amount that would take place were people to decide for reasons related to their medical and psychological well-being. The second reason makes individual health and well-being the desired end and the right amount of testing the amount that results when each individual is free to pursue that end. The first reason makes the overall promotion of health the goal and the "right" amount that which best achieves this outcome.

One would clearly need to say more to argue convincingly for either approach. The important point is that one must present an argument for why certain reasons ought to affect testing decisions and not others-which Diver and Cohen fail to do. Greely and others do just that by arguing for antidiscrimination protection (which has the effect of shielding individuals deciding whether to undergo genetic tests from consideration of some reasons) on the grounds that this legislation will promote health. While this argument rests on important empirical assumptions that must be examined (discussed above) and important ethical issues that require consideration (to be discussed below), this argument for protection from genetic discrimination has the virtue of providing a reason for the claim that only some considerations ought to affect individual testing decisions.

\section{b. Ethical Complications}

The argument that the government ought to enact legislation forbidding genetic discrimination, particularly in the context of health insurance, raises two important ethical concerns. First, one must ask whether it is right to pass laws that ensure that only some of those who are entitled to receive a benefit receive it. To those who believe that everyone ought to have access to healthcare, the fact that many people do not have health insurance is unjust. The interesting point that the current debate about legislation targeting genetic discrimination poses is whether remedying this injustice for some compounds the moral wrong to others by adding unfairness to injustice.

An anecdote-the truth of which I cannot verify-explains well the distinction between justice and fairness that I employ here. As I have heard the story told, Professor Sidney Morgenbesser of the Philosophy department of Columbia University was called for jury duty in New York City. In voir dire, he was asked whether the police had ever treated him unjustly or unfairly. The case before the court was, apparently, one dealing with alleged police brutality. Professor Morgenbesser replied, "unjustly yes, but not unfairly." Confused, the judge asked the philosopher to explain. Morgenbesser related that during the anti-war protests on the Columbia campus during the Vietnam War, he participated in a sit-in of the school's administrative offices. The police arrived and arrested the protesters, beating Morgenbesser in the process. This was unjust, according to the Professor, as the police ought not to have beaten him during the arrest. He was not resisting arrest and would have come with the police willingly. But it was not unfair, Morgenbesser went on, since the other protesters were also beaten. Following Morgenbesser's distinction between justice and fairness, then, legislation forbidding genetic discrimination may remedy injustice to some while adding unfairness to the injustice of being without health insurance to others.

Second, and perhaps more problematic, laws forbidding genetic discrimination in health insurance may work to thwart the development of the political constituency necessary to enact legislation providing healthcare coverage to all. Advances in genetic science could help foster the requisite sense of community needed to make it 
politically possible to enact some form of universal access to healthcare. As scientists learn more about genetic diseases, few of us are likely to escape some genetic flaw. Perhaps this sense of common fragility will help us to feel connected to and responsible for those who lack access to health insurance. If so, legislation forbidding genetic discrimination could work to undermine this momentum. In addition, because it is the relatively privileged who currently have access to genetic testing and who thus could stand to lose their insurance if genetic discrimination was permitted, those who would benefit from antidiscrimination protection are those with the most political power to bring about change. ${ }^{77}$

Assuming, for the sake of argument, that legislation forbidding genetic discrimination will indeed promote health by ensuring that the potential of genetic science is realized, who will benefit? Those individuals who would otherwise be deterred from testing and gaining information that could enhance their own health will benefit. In addition, if further research is not stymied by lack of participation and that research yields new discoveries, people who might otherwise become sick with genetic diseases in the future could be treated or cured, which is a significant benefit. But, if passage of antidiscrimination protection would indeed dampen the political pressure for universal healthcare coverage, then one must look closely at who loses out so that the benefits of genetic science may be realized. While it is not the poorest among us who lack healthcare or health insurance, as Medicaid insures healthcare for the poorest, those Americans without healthcare generally come from the ranks of the near poor or working poor. ${ }^{78}$ Accordingly, legislation forbidding genetic discrimination may turn out to exacerbate inequality.

Moreover, the gains made possible by advances in genetic science are likely to be reaped by those who are already relatively privileged. Trudo Lemmens stresses this argument about deepening unfairness, pointing out that "[p]eople who will seek information on their genetic susceptibility will be those who have the financial means to undergo testing or those who have a good insurance plan (and thus already benefit from better healthcare)." justly if it enacts legislation that will enhance health, but not evenhandedly. While one cannot know who will develop genetic diseases in the future, and those diseases are likely to affect the rich and poor alike, not everyone who stands to benefit from these health advances will actually do so. Those without access to healthcare are also likely to be without access to new genetic therapies. If legislation forbidding genetic discrimination also lessens the chance of achieving universal access to healthcare, then these laws may well cluster their benefits among the relatively privileged and their burdens among the less well-off.

Like the empirical questions identified above, these ethical concerns also require further study. First, I identified the tension between remedying injustice for some by ensuring access to health insurance, while adding unfairness to injustice for those left behind. In order to make the argument that special legislation forbidding genetic

77 Chetan Gulati emphasizes this point. Chetan Gulati, Genetic Antidiscrimination Laws in Health Insurance: A Misguided Solution, 4 QUINNIPIAC HEALTH L.J. 149, 168 (2001) (arguing that laws prohibiting genetic discrimination work to protect the health insurance structure from more systemic revision). Sonia Suter makes an interesting related observation by pointing out that the poor are disproportionately affected by non-genetic factors that affect health, like pollution and violence, and that therefore, special genetic legislation may exacerbate inequality. Suter, supra note 7, at 719.

78 Walter L. Stiehm, Poverty Law: Access to Healthcare and Barriers to the Poor, 4 QUINNIPIAC HEALTH L.J. 279, 285 (2001).

79 Lemmens, supra note 5, at 380. 
discrimination is warranted, one must assess whether the unfairness of helping only some of those entitled to a benefit ought to defeat the policy. Second, the claim that forbidding genetic discrimination may stand in the way of universal access to healthcare is quite speculative and difficult to weigh. Thus, how much should we discount the exacerbation of inequality in light of the speculative nature of this supposition? This is a difficult question that requires further consideration.

\section{The Expressivist Argument}

Much of the commentary about genetic discrimination refers to the history of eugenics both in this country and in Europe. For example, Professor Aviam Soifer and Miriam Wugmeister warn that "[t]he tragic history of eugenics also casts a long shadow over contemporary claims regarding new knowledge about human genetics." 80 Professor Lori Andrews argues that the justification offered by insurers for their use of genetic information in classifying risks "is similar to that used in the earlier eugenics movement-that healthy people (that is, people with 'good genes') should not have to support people who have or may develop genetic diseases (people with 'bad genes')." ${ }^{, 81}$ It seems obvious that this history is relevant to the question of whether genetic discrimination is wrong as well as to whether genetic discrimination is different from discrimination on the basis of health in a manner that warrants special legislation. Exactly why this history matters, however, is not clear from the arguments currently found in the literature. The expressivist argument presented in this Article makes it clear why this history is relevant; it is relevant because it changes the social meaning of current practices. Genetic discrimination expresses something different because of our experience with illegitimate uses of genetics. According to an expressivist conception of what makes discrimination wrong, this is important because it is the expressive dimension of policies that draw distinctions between people which determines whether these policies discriminate wrongfully.

The following argument is a close cousin of the argument that genetic discrimination is wrong because it is stigmatizing. Although "stigma" is a somewhat elusive term, it arguably calls attention to the effect of a law or policy. An expressivist approach, in contrast, focuses on what is expressed by a law or policy, regardless of whether this expression actually harms an identifiable group in a particular way. The expressivist argument is also related to Wolf's argument about "geneticism." 82 Both make the social dimension in which a particular discriminatory practice occurs highly relevant in determining its character. However, Wolf's argument is different in that it does not explain how or why the fact that genetics has been used to subordinate people matters in assessing whether genetic discrimination in insurance or employment is morally problematic.

The argument below explores the intuition that the history of eugenics matters in assessing whether and when genetic discrimination is wrong. It is a sympathetic reconstruction of an argument that is implicit in the literature on genetic discrimination but which has not been clearly articulated and evaluated.

80 Aviam Soifer \& Miriam Wugmeister, Mapping and Matching DNA: Several Legal Complications of "Accurate" Classifications, 22 HASTINGS CONST. L.Q. 1, 25 (1994).

81 Lori B. Andrews, Past as Prologue: Sobering Thoughts on Genetic Enthusiasm, 27 SETON HALL L. REV. 893, 904 (1997).

82 See Wolf, supra note 7 and accompanying text. 
a. What Is an "Expressive" Theory?

An expressive theory is one in which what an action expresses-its meaning-is relevant in determining its moral permissibility. ${ }^{83}$ In this sense, it differs from the more familiar way one judges the moral permissibility of actions, in which it is the intent of the actor, the effect of the action, or both, that are central. For example, in criminal law, both intent and effect are relevant in judging the moral acceptability of an action. If someone accidentally kills another, the person will not likely be guilty of murder, which requires that the actor have a particular intent. In addition, if someone intends to kill another but fails, she may only be guilty of attempted murder and will thereby be punished more lightly because her action did not cause significant harm. To claim that the expressive character of the action is what matters in a particular instance is to call attention to a third dimension of an action. For example, if I spit on a homeless person, my action is wrong because it expresses disrespect. The effect of that action is clearly far less important than what it expresses. The spit may be unpleasant, but its unpleasantness is not what makes the action wrong.

In the above example, perhaps it is my intent to be disrespectful that makes the action wrong. A theory in which the expressive character of action is important is one in which actions can be morally wrong even when done accidentally or without the specific intent to convey the meaning the action expresses. Consider the following example. The Governor of South Carolina decides to fly the Confederate flag over the State House with the intent of building a sense of loyalty to the state and thereby increasing social cohesiveness. ${ }^{84}$ This action would be morally problematic despite the innocuous intent of the Governor, and not merely because of the negative effect it is likely to have on social harmony. The action is morally troublesome because of what flying the Confederate flag expresses, regardless of whether the Governor intends to convey that meaning. Given the history of slavery and discrimination in the South, as well as the historical association of the Confederate flag with that history, flying the flag has a meaning that is beyond the control of the Governor's intent. To say that this meaning is relevant in assessing whether flying the flag is wrong is to emphasize our responsibility for how our actions are likely to be understood. So even if I do not intend disrespect by spitting, I cannot spit blamelessly, as the meaning of spitting on someone in our culture is as an act of disrespect. A theory that emphasizes the expressive dimension of action contends that the fact that spitting expresses disrespect matters.

One caveat: to say that the expressive dimension of action matters is not to say that it is all that matters. Intent and effect may also be relevant. However, the expressive dimension is relevant in a way that cannot be reduced to intent and effect. The expressive character of an action is relevant even when the meaning of the action is not what the actor intends to express (intent) and even if that meaning is not what is in fact communicated (effect).

Recently, attention to the expressive dimension of action has become important in constitutional law, particularly in interpreting the Establishment Clause of the

83 For a discussion of the relevance of the expressive dimension of action, see Symposium, The Expressive Dimension of Governmental Action: Philosophical and Legal Perspectives, $60 \mathrm{MD}$. L. REV. 465 (2001).

84 For a similar discussion regarding flying the Confederate flag over the State House in South Carolina, see James Lindemann Nelson, The Meaning of the Act: Reflections on the Expressive Force of Reproductive Decision Making and Policies, IN PRENATAL TESTING, supra note 10, at 196. 
First Amendment and the Equal Protection Clause of the Fourteenth Amendment. In some cases, the U.S. Supreme Court has held that the correct manner by which to judge whether holiday displays unconstitutionally establish religion is to look at how those displays are likely to be interpreted by a hypothetical reasonable observer in our culture. ${ }^{85}$ In the area of Equal Protection, the development has been less a phenomenon of the Court and more a small movement among academic commentators. ${ }^{86}$ Here, the claim is that the right way to interpret whether laws or state policies violate the Equal Protection Clause is to focus on the meaning or expressive dimension of the law or policy. Current doctrine makes intent the touchstone of an Equal Protection violation. ${ }^{87}$ The dominant critique of that doctrine would focus instead on the effect of laws and policies. ${ }^{88}$ The expressivist approach, in contrast, looks at the law's objective meaning.

But why focus on meaning and how can such meaning be described as objective? While I cannot here develop the entire argument for understanding the Equal Protection Clause in expressive terms-as that would (and did) require an article on its own-let me just briefly restate my view. Laws and policies draw distinctions between people in a myriad of ways, some of which our intuitions tell us are morally troubling and some of which are not. Pre-Brown racial segregation of public schools seems paradigmatically wrong and in violation of Equal Protection. ${ }^{89}$ Single-sex admissions at the Virginia Military Institute seems more ambiguous, though it was ruled unconstitutional by the Supreme Court. ${ }^{90}$ Single-sex bathrooms at state schools, such as the University of Maryland School of Law, seem unproblematic. If we use the term "discrimination" to describe each of these cases, and others where people are treated differently on the basis of some trait or characteristic, it is clear that not all discrimination is morally troubling or unconstitutional. A law firm's decision to hire only law graduates in the top ten percent of their law school class-thereby discriminating against the remaining ninety percent of each class-seems fine, but a decision to hire only women seems wrong. Although state-sponsored single-race education seems wrong, single-sex education seems more ambiguous.

85 See Lynch v. Donnelly, 465 U.S. 668, 692 (1984) (O'Connor, J., concurring) (arguing that "[w]hat is crucial is that a government practice not have the effect of communicating a message of government endorsement or disapproval of religion"); County of Allegheny v. ACLU, 492 U.S. 573, 573 (1989) (adopting the endorsement test of O'Connor's concurring opinion in Lynch when finding that a crèche in a city's holiday display violated the First Amendment's Establishment Clause while a menorah did not); see also Hellman, Expressive Dimension, supra note 9, at 24-26 (discussing Lynch and Allegheny and the scholarship they engendered).

86 See, e.g., Elizabeth S. Anderson \& Richard H. Pildes, Expressive Theories of Law: A General Restatement, 148 U. PA. L. REV. 1503 (2000) (offering a general defense of why the expressive dimension of state action matters); Hellman, Expressive Dimension, supra note 9 (arguing that the only way to determine whether classifications by state actors wrongly discriminate is to focus on the what the state action expresses); but see Matthew D. Adler, Expressive Theories of Law: A Skeptical Overview, 148 U. PA. L. REv. 1363 (2000) (challenging whether any of the so-called expressive theories really are theories which make the permissibility of law depend on its expressive dimension).

87 See Hellman, Expressive Dimension, supra note 9, at 1-2 (discussing Washington v. Davis, 426 U.S. 229 (1976), as the case that marked the point at which the intent-based understanding of the Equal Protection Clause became the dominant understanding of the Supreme Court).

88 See Hellman, Expressive Dimension, supra note 9, at 1 (discussing the work of Kenneth L. Karst and Andrew Koppelman).

89 See Brown v. Bd. of Educ., 347 U.S. 481 (1954).

90 U.S. v. Virginia, 518 U.S. 515 (1996). 
Articulating a general theory of when and why discrimination is wrong is not an easy task. If the Supreme Court's Equal Protection case law is an attempt to do so, it is a confusing and often conflicting articulation. Taking the dominant strands of that doctrine, the Court's answer appears to be that discrimination is wrong when the law or policy is enacted for the wrong sort of reason, that is, with invidious intent. While it is notoriously difficult to clearly articulate which intentions are in fact invidious, the Court is fairly clear that the actual subjective mental state of the people responsible for the law or policy at issue is what matters. ${ }^{91}$ This theory has been roundly criticized for many reasons:

Briefly, the intent doctrine has been criticized as incoherent because determining the intent of a group like a legislative body is both philosophically as well as practically problematic. Second, even at the individual level, it is often difficult to know or assess the precise reasons for an individual's action. Unconscious or subtle motives may guide us without our recognition of their influence. Third, moral responsibility for actions extends beyond those actions one specifically intends. Surely the failure to take the interests of a particular group into account-indifference rather than animus-is to deny those affected the law's equal protection. Fourth and finally, while intent is relevant to assessing the moral culpability of legislative actors, courts ought to interpret the Equal Protection Clause to police how people are treated by their government. We ought to be interested in the permissibility of laws, not in the purity of legislative motives. ${ }^{92}$

But neither is focusing on effect, the dominant alternative vision, a helpful way to sort the acceptable from the unacceptable instances of discrimination. First, one faces the difficult task of articulating what effects are problematic. The standard answer is that those effects that entrench caste-like distinctions in our society violate Equal Protection. The problem with this understanding of Equal Protection, however, is that the clause then becomes a general guarantee of substantive social justice. As I have argued previously, this understanding of Equal Protection is misguided:

Equal Protection does speak to issues of social justice, but it is best understood as a specific protection. While it is difficult to specify precisely what Equal Protection protects-indeed, that is the project of this Article as well as a surfeit of others-we weaken its power and dilute its special appeal to deep and shared moral intuitions if we interpret it as a general guarantee of distributional fairness. For example, the current flat tax proposal would violate an antisubordination conception of Equal Protection if it turned out that the law worked to entrench racial inequality. While a flat tax may be

91 See, e.g., Personnel Adm'r v. Feeney, 442 U.S. 256 (1976) (citing the Court's explanation that " discriminatory purpose... implies more than intent as volition or intent as awareness of consequences, [i]t implies that the decisionmaker... selected or reaffirmed a particular course of action at least in part 'because of,' not merely 'in spite of,' its adverse effects" (footnotes and citation omitted)); see also Hellman, Expressive Dimension, supra note 9, at 30-34 (discussing the claim that subjective intent is what has mattered to the Court in assessing violations of Equal Protection in most of the case law); but see C. Edwin Baker, Outcome Equality or Equality of Respect: The Substantive Content of Equal Protection, 131 U. PA. L. REV. 933 (1983) (arguing that the Court's requirement of invidious intent is used and ought to be used to denote objective rather than subjective intent).

92 Hellman, Expressive Dimension, supra note 9, at 4 (footnotes omitted). 
inimical to the demands of justice in that justice may well require redistribution, it seems a stretch to claim that the flat tax denies people the Equal Protection of the laws. To read the Clause as equivalent to a general requirement of social justice is to sap the Equal Protection Clause of its unique potency. ${ }^{93}$

The alternative to these two familiar ways of understanding the Equal Protection Clause shifts the focus of the courts' attention to the expressive dimension of laws. Single-sex bathrooms in state universities do not violate Equal Protection because the meaning in our culture of segregating people by sex for bathroom use is not denigrating. Single-race bathrooms violate Equal Protection because that policy carries a different meaning in our culture, a meaning that conflicts with the state's obligation to treat everyone with equal respect. Similarly, a decision by a District Attorney's office to hire only men on the theory that men make better prosecutors because they are more aggressive than women violates the Clause. Yet, the decision to hire only law graduates in the top ten percent of their graduating class on the theory that they are more likely to be successful prosecutors does not. Despite the current doctrine's focus on the degree of fit between the classification and its target, it does not matter whether men really are more aggressive then women. In fact, as feminist scholars have rightly pointed out, stereotypes often fit quite well because of the history of ubiquitous gender stereotyping or because of real differences between men and women. ${ }^{94}$ The use of sex as a proxy for lawyerly skill is not wrong because it is irrational or because it harms the group left out. After all, the use of grades as a proxy for legal ability may turn out to be equally irrational and it equally harms those not hired. The difference between these two instances of discrimination is that the first expresses that some people do not equally deserve concern and respect while the second policy does not similarly denigrate those with lower grades. The first policy expresses denigration while the second does not because it is interpreted in the context of American history, a history replete with denials of the intellectual capacity of women.

This summary of the expressive conception of what makes discrimination wrong is necessarily brief, and questions clearly remain. Rather than attempting to fully articulate the argument in favor of an expressive conception of wrongful discrimination, I will assume its reasonableness here. Instead, I examine the strength of the argument that genetic discrimination is wrong because of what it expresses. Much of the critique of genetic discrimination seems to implicitly reach towards this argument. Some of the questions that remain about the expressive theory of discrimination generally will be explored further by looking at it in the context of genetic discrimination. In particular, one may wonder how to determine

93 Id. at 5.

94 Catherine A. Mackinnon, Sexual harassment of WORKing WOMEn 101-06 (1979). Contrasting two approaches to sex discrimination which MacKinnon terms the "difference approach" and the "inequality approach," she emphasizes that

[w] hat the second approach grasps, and the first does not, is that it is not only lies and blindness that have kept women down. It is as much the social creation of differences, and the transformation of differences into social advantages and disadvantages, upon which inequality can rationally be predicated. Discrimination is often irrational. But under the inequality approach, that is not all, nor even primarily, what is unjust about it. What is unjust about sex discrimination is that it supports a system of second-class ld. at 105 . status for half of humanity. 
the meaning of a particular law or policy and whether that meaning is likely to be contested. These important questions will be addressed below. ${ }^{95}$

\section{b. The Claim: Genetic Discrimination Is Wrong Because of What It Expresses}

According to the expressive theory of wrongful discrimination, whether discrimination is wrong depends on the expressive dimension of the law or policy at issue. Applying this theory to genetic discrimination requires that one ask what a policy of genetic discrimination expresses. Clearly, it is not simple or straightforward to determine the social meaning of genetic discrimination. Fixing social meaning is an interpretive and inherently contestable task. However, drawing on the literature criticizing genetic discrimination, we can glean meanings that others have found in genetic discrimination, two of which recur enough to be worthy of attention. First, one might find that genetic discrimination expresses a kind of genetic determinism, that genes fully and completely determine one's fate. ${ }^{96}$ Second, one might find that the practice of making insurance, employment or other decisions on the basis of a person's genetic traits expresses that some people have intrinsic flaws that render them less good, less worthy and less fit to be part of our community. ${ }^{97}$ Both of these meanings seem troubling.

The fact that a discriminatory policy's meaning is troubling is not enough, however, to render it wrongful. Consider first the understanding of genetic discrimination as expressing genetic determinism. Genetic determinism may offend our sense of personal identity and dignity because it suggests a limited ability to control one's destiny and it may be misinformed as it inaccurately overstates the role of genetics in determining our futures. However, the mere fact that genetic discrimination expresses genetic determinism does not make genetic discrimination wrong. According to my theory of when classifications constitute wrongful discrimination, only those meanings that conflict with the principle that each person is equally worthy of concern and respect render a policy or practice wrongfully discriminatory. Genetic determinism tends to negate the importance of individual behavior and uncertainty in how our lives play out, but it does so across the board. To assert that genes are "our future diaries," to borrow the metaphor offered by Thomas Murray, ${ }^{98}$ may be reductionist as well as inaccurate. It may ignore the creative individual contribution of free will and the importance of serendipitous chance encounters, but it negates the individuality and randomness in everyone's life equally. As such, the fact that genetic discrimination may express a kind of genetic determinism does not render such discrimination wrongful because this meaning does not offend equality.

95 See infra notes $96-98$ and accompanying text.

96 Leon Kass finds this to be the meaning of our society's enthusiasm for genetic science. Leon R. Kass, Triumph or Tragedy? The Moral Meaning of Genetic Technology, 45 AM. J. JURIS. 1 (2000); Murray, supra note 12, at 68 (finding that the concern with "genetic prophesy"-a phrase borrowed from Nancy Wexler-to be one of the central reasons that some commentators worry about genetic discrimination); Dorothy C. Wertz, Society and the Not-So-New Genetics: What Are We Afraid of? Some Future Predictions from a Social Scientist, 13 J. CONTEMP. HEALTH L. \& POL'Y 299, 308 (1997) (arguing that a genetic essentialism has dominated our history except during a few periods, and that this view of genetics and its power shapes how we view issues related to genetics).

97 This conception of genetic discrimination seems implicit in the critiques that emphasize the importance of the history of America's eugenic practices. See Soifer \& Wugmeister, supra note 80; Andrews, supra note 81.

98 Murray, supra note 12. 
Genetic discrimination also expresses a second and more problematic meaning. Several commentators emphasize the history of eugenics in order to imply that genetic discrimination is different from discrimination on the basis of health because the history of the misuse of genetic information colors the way that our society understands the practice of genetic discrimination. Read with this history as a backdrop, the meaning of genetic discrimination may be that those with genetic flaws, or more flaws than average, are less worthy or important for that reason.

If this understanding of the meaning of genetic discrimination is correct, then genetic discrimination may be wrong for that reason. This argument distinguishes genetic discrimination from discrimination on the basis of health and thus can support the claim that genetic discrimination is exceptional. According to this view, genetic discrimination is different because the social meaning of genetic discrimination is different. The strength of this argument depends on the strength of the claim that genetic discrimination does indeed express disrespect for people with genetic mutations that especially predispose them to disease or disability. To assess the soundness of this interpretive assessment, it will be helpful to briefly review our society's previous encounters with genetics.

\section{THE HISTORY OF EUGENICS AND ITS ROLE IN FIXING THE MEANING OF GENETIC DISCRIMINATION}

This section examines the claim that that the meaning of genetic discrimination is powerfully affected by the history of the misuse of genetics. This section will discuss aspects of that history which may inform the way genetic discrimination is likely to be perceived. Although my treatment of the subject is brief, ${ }^{99}$ it is sufficient because a claim about the meaning of a practice refers to how that practice-genetic discrimination-is likely to be perceived or understood by people with an ordinary amount of knowledge about their society's history.

The beginning of the systematic, scientific understanding of genetics and its effect on health stretches back approximately 150 years. ${ }^{100}$ It was not until the twentieth century, however, that these scientific developments began to have significant social consequences. Interestingly, the attraction to genetics and its social possibilities came, both in the United States and in Great Britain, from both the right and the left of the political spectrum. ${ }^{101}$ Scientists and social critics saw genetics as offering tremendous potential. Rather than focusing on therapeutic efforts for people with genetic diseases, however, scientists and social reformers were mainly interested in the promise of genetics to affect reproductive choiceseugenics.

The social policies that new genetic knowledge generated were eugenic in both the positive and negative sense. First, eugenicists were interested in encouraging reproduction by those perceived as having "better" genetic endowments. For example, in the 1920s, state fairs around the country sponsored "Fitter Families" contests. Along with prizes for the tomatoes and hogs, there were prizes for "Grade

99 For a thorough discussion of the history of the eugenics movement of the United States and Great Britain, see Daniel J. Kevles, In the Name of Eugenics: Genetics and the Uses of HUMAN HEREDITY (1985).

$100 \mathrm{Id}$. at 3-19 (detailing Francis Galton's work in the mid nineteenth century).

101 Id. at 63 (describing that in the early part of the twentieth century, genetics was popular with both radicals and conservatives in the United States and England). 
A individuals" in the "human stock" category. ${ }^{102}$ This interest in encouraging the "better" to reproduce was coupled with a fear that the "defective" were overproducing. As a result, the feminist cause of birth control became more broadly acceptable because it offered the promise that the birthrates of the lower classes could be contained. This negative eugenic purpose is well-illustrated in the disturbing quotation from Havelock Ellis in Dr. Daniel Kevles's history of eugenics movements in the United States and Great Britain: "The superficially sympathetic man flings a coin to the beggar; the more deeply sympathetic man builds an almshouse for him so that he need no longer beg; but perhaps the most radically sympathetic of all is the man who arranges that the beggar not be born."

In the United States, the eugenics movement had racial overtones as well. The "better" stock was presumed to be "white Protestants of Northern European Stock," while the lesser stock was made up of "blacks and Jewish and Catholic immigrants." $" 104$ The first widespread use of intelligence testing, which occurred in the armed forces, offered supposedly objective data for these conclusions. This data consisted of information showing that blacks consistently tested lower than whites. The fact that the test measured education as much as intelligence was largely ignored. ${ }^{105}$

It was not until the second World War that the use of genetic science for eugenic purposes was discredited. Revelation of Nazi atrocities did much to halt the popularity of eugenics in the United States as well as to affect later perception of eugenics. For example, when the genetic counseling profession was just beginning to develop in 1947, Dr. Sheldon Reed-one of its founders-chose the term "genetic counseling" to replace "genetic hygiene" and "genetic advice" which had come to be seen as tainted by eugenics. ${ }^{106}$ Moreover, the profession adopted the credo of "nondirectiveness"- a commitment to provide information, but not advice to patients seeking genetic services-in response to the problematic history of eugenics, especially in the context of reproduction. ${ }^{107}$

Considering this brief description, one can perhaps conclude that our collective consciousness regarding the misuse of genetic science in the United States, as well as the powerful example of Nazi Germany, has influenced how genetics is currently perceived. The question we are considering is whether genetic discrimination expresses disrespect or unequal concern. The social meaning of genetic discrimination, understood against this historical background, may well denigrate the equal value of people with genetic disease. Given the misuse of genetics in our past, this claim is surely plausible.

$102 \quad I d$. at 62.
$103 \quad I d$. at 90.
$104 \quad I d$. at 75.

$105 I d$ at 83 (explaining that "[c]learly a variety of causes, including the cultural bias of the Army tests themselves and the poor education of many of the test takers, might have accounted for the results[,] . . . [y]et the supposedly objective test data further convinced eugenically minded Americans not only that mental deficiency was genetically determined but that so was intelligence").

106 Wertz, supra note 96, at 306.

107 Id. (explaining that "[i]t is unlikely that there would have been such emphasis on nondirectiveness had genetics begun as a pediatric or adult specialty outside the context of reproduction"). 


\section{A. How Strong Is the ARgument?}

Interestingly, some of the critics of special legislation prohibiting genetic discrimination object to these laws by arguing that the social meaning of genetic discrimination is not denigrating, though they do not label the argument in this manner. For example, Diver and Cohen point out that understanding a condition as a genetic disease can in fact make having it less stigmatizing. To illustrate this point, they ask us to "[c]onsider the characterization of alcoholism as a disease, the relabeling of 'senility' as Alzheimer's disease, or the emerging consensus that obesity has a strong genetic component." most common genetically influenced diseases, such as heart disease or cancer, elicit reactions of sympathy and solicitude far more than fear and aversion."109

Although this is an important criticism, it does not respond directly to the expressivist argument for prohibiting genetic discrimination. The reason it is inapposite has much to do with the ambiguity regarding what one means by the term "stigma." Diver and Cohen's point refers to how the particular people with genetic conditions are treated. The expressivist argument, however, focuses on the meaning expressed to everyone by the practice of genetic discrimination: does it convey the message that people with genetic conditions are less worthy of our concern and respect than others? While it may be true that an individual is pitied rather than blamed for being obese or alcoholic in that the genetic link tends to absolve individual responsibility for the condition, it may remain true that social practices which continue to treat the obese or alcoholic and others with genetic conditions less well express that the lives of these people are less valuable. Diver and Cohen's other examples, heart disease and cancer, illustrate this point even more clearly. ${ }^{110}$ While the individual may elicit sympathy for having the condition, the meaning expressed in the practice of genetic discrimination may still convey that the lives of these "flawed" individuals is less important and less valuable.

The fact that Diver and Cohen's critique is not persuasive does not settle the question whether genetic discrimination expresses that people with genetic conditions are less worthy of concern and respect. Just as determining the meaning of a novel or play is an interpretive exercise about which people can disagree, the determination of the meaning of a social practice can also result in disagreement. Indeed, the same thing can be said about determining what a statute or prior case law requires. In each of these cases, the interpretation is open to dispute. But this contestability surely does not render the thing interpreted (a social practice, a novel or a law) meaningless. As Professor Ronald Dworkin explains about the nature of law, some interpretations of current law are ruled out by prior law, while a range of others fit reasonably well with current law, making them plausible readings of the law. ${ }^{111}$ So, how should one choose among plausible readings of the meaning of genetic discrimination? To answer this question, it may be helpful to examine prenatal genetic testing and its social meaning. This example is likely to be helpful

108 Diver \& Cohen, supra note 6, at 1478.

109 Id.

$110 \quad l d$

111 RONALD DWORKIN, LAW'S EMPIRE 228-38 (1986). Dworkin uses the example of a chain novel to explain what a judge does in deciding a case. The new decision is like the next chapter in an on-going novel. As such, this new chapter must fit reasonably well with what has come before. According to Dworkin, there will be several reasonable interpretations of prior law that make possible a range of ways the new case can be decided. The judge must then choose among them, according to Dworkin, guided by the principle that he or she should make our law "the best it can be." Id. at 229. 
because the critique of that practice by disability advocates focuses precisely on the expressive dimension of prenatal genetic testing.

\section{B. Prenatal Genetic Testing: What Does that Practice Express?}

Prenatal genetic testing is a procedure by which cells from a developing fetus are tested for genetic mutations associated with particular diseases or disabilities. ${ }^{112}$ It is generally performed so that the woman or couple can abort the fetus if a serious anomaly is found. Since amniocentisis, the most common form of prenatal genetic testing, carries some risk of inducing a spontaneous abortion, it is unlikely that the procedure would be offered in the routine fashion that is common today if it were generally undertaken for its informational value alone. ${ }^{113}$

Prenatal genetic testing for disease and disability and the selective abortion that generally follows a finding of an abnormality, or more accurately the routine way in which prenatal testing is offered, ${ }^{114}$ has become the subject of criticism by disability rights advocates. In particular, many critics argue that prenatal testing and selective abortion for disability are morally problematic because of what that practice says or expresses about the value of the lives of living people with disabilities. ${ }^{115}$ These critics do not oppose abortion per se. In fact, the critics of testing explicitly and ardently support a woman's right to reproductive freedom. Rather, they oppose the fact that prenatal testing has become a part of standard prenatal care. These critics contend that the normalization of prenatal screening for disability expresses that these disabilities are incompatible with a meaningful and worthwhile life. The expressive theory of discrimination captures the intuition that there may be something morally troubling about selective abortion for disability that has nothing to do with the rights of the disabled fetus.

Disability activists emphasize that the routine nature of testing carries two related messages. First, the routine availability of testing changes the landscape for women or couples who seek prenatal care. As Bruce Jennings points out, offering prenatal screening changes the terrain for couples whether they accept the offer and screen or reject it." ${ }^{116}$ He provides the following example: "Suppose a couple is offered a test for Tay-Sachs and decides to forego it. If the child eventually becomes symptomatic with the disease, that cannot be considered a tragic surprise or shock to the parents, but rather stands as an example of willful and deliberate choice."117

112 See Powell, supra note 27 , at $44-48$ (discussing the history and current status of available prenatal testing).

113 Id. at 44-45.

114 It is more productive to view the routine practice of offering prenatal tests and selective abortions as expressing a problematic meaning rather than focusing on the expressive dimension of the individual woman's choice to abort a disabled fetus, as that decision is usually carried out privately. As Eva Feder Kittay notes, "A woman rarely says: 'Listen up, world. I am having an abortion based on a diagnosis of fetal abnormality and I am about to tell you why I choose to abort a fetus with such an abnormality." Eva Feder Kittay \& Leo Kittay, On the Expressivity and Ethics of Selective Abortion for Disability: Conversations With My Son, in PRENATAL TESTING, supra note 10 , at 186.

115 See Bruce Jennings, Technology and the Genetic Imaginary: Prenatal Testing and the Construction of Disability, in Prenatal Testing, supra note 10, at 124; Marsha Saxton, Why Members of the Disability Community Oppose Prenatal Diagnosis and Selective Abortion, in Prenatal Testing, supra note 10, at 147; Kittay \& Kittay, supra note 114, at 165 (Leo Kittay's contribution is particularly noteworthy); Adrienne Asch, Why I Haven't Changed My Mind About Prenatal Diagnosis: Reflections and Refinements, in PRENATAL TESTING, supra note 10, at 234.

116 Jennings, supra note 115 , at 135.

117 Id. at 134. 
Second, the fact that prenatal testing programs exist and are common suggests that the "normal" response to a positive test result for disability is abortion. ${ }^{118}$ Disability activists focus on the meaning expressed by the supposition, which girds the routinization of testing, that most women will want to abort for certain disabilities. They argue that this supposition expresses that these disabilities provide good reasons to abort because the lives of people with these disabilities are not worth living or, alternatively, that raising a child with such disabilities is so difficult that the joys that the child occasions do not compensate for the problems the child's needs engender. As Dr. Marsha Saxton describes, "For people with disabilities, 'the message' implicit in the practice of abortion based on genetic characteristics is . . : 'It is better not to exist than to have a disability.' Your birth was a mistake. Your family and the world would be better off without you alive." 19 Professor Adrienne Asch poignantly describes the meaning she sees in the practice of testing:

People with just the disabilities that can now be diagnosed have struggled against an inhospitable, often unwelcoming, discriminatory, and cruel society to fashion lives of richness, of social relationships, of economic productivity. For people with disabilities to work each day against societally imposed hardships can be exhausting; learning that the world one lives in considers it better to 'solve' problems of disability by prenatal detection and abortion, rather than by expending those resources in improving society so that everyone-including those people who have disabilities-could participate more easily, is demoralizing. It invalidates the effort to lead a life in an inhospitable world. $^{120}$

This meaning is surely one that is morally problematic as it certainly offends the principle of equal concern and respect. What is less clear is whether disability activists are correct in reading the routine practice of prenatal testing and selective abortion as carrying this message.

In an exemplary model of moral inquiry, the Hastings Center gathered together a group of people to discuss the disability rights critique of prenatal testing at several meetings over a two-year period. ${ }^{121}$ The group included participants who found that critique of testing persuasive and others who did not; it included disabled and nondisabled participants as well as some with experience as parents of disabled children. The group was also diverse in professional backgrounds, including philosophers, genetic counselors, physicians, educators, writers, lawyers, participants from public health and psychiatry. ${ }^{122}$ At these meetings, members of the discussion group addressed the precise question of what the practice of testing and selective abortion expresses. All did not believe that the meaning of the practice was as its critics found it to be. The disagreement largely centered on the question of whether selective abortion for disability is the kind of act whose symbolism is clear enough to carry a distinct meaning. ${ }^{123}$

118 Saxton, supra note 115 , at 148

119 Id. at 160

120 Asch, supra note 115 , at 240

121 Erik Parens \& Adrienne Asch, The Disability Rights Critique of Prenatal Genetic Testing: Reflections and Recommendations, in PRENATAL TESTING, supra note 10, at 3, 5.

122 Erik Parens \& Adrienne Asch, Introduction to PRENATAL TeSTING, supra note 10, at ix, $\mathrm{x}$.

123 Id. 
These counter-critics (i.e., those who were unconvinced that the meaning of prenatal testing and selective abortion denigrates the lives of living people with disabilities) make three important points. First, they argue that there are simply not enough shared reference points to confidently define the meaning of prenatal genetic testing. ${ }^{124}$ Professor James Lindemann Nelson compares the practice of prenatal testing with the act of flying a Confederate flag atop a public building (an act which he sees as carrying a distinct meaning) and stresses that the "semantic force of diagnostic tests and pregnancy termination is not well defined within our shared symbol systems, and whether one can be justified in attributing to such practices clear messages, disrespectful or not, needs careful consideration." 125

Moreover, if the meaning seems clear, the counter-critics argue, this is not because the practice of routine genetic testing in the prenatal context is denigrating, but rather because the background context of unjust treatment of people with disabilities makes it seem denigrating. ${ }^{126}$ Context can legitimately participate in fixing meaning (think of the Confederate flag example). Rather, the counter-critics argue that, since the symbolic significance of prenatal testing is so indeterminate, the context is doing too much work. Professor Eva Feder Kittay explains: "Because codes concerning acts of abortion and selective abortion are so underdeveloped and so contested, context is virtually, though not entirely, determinative."127

Third, the counter-critics argue, if prenatal genetic testing expresses something, it is something about the value of the disability, not the value of a person with such a disability. As Dr. Bonnie Steinbock emphasizes, "[f]rom the fact that a couple wants to avoid the birth of a child with a disability, it just does not follow that they value less the lives of existing people with disabilities, any more than taking folic acid to avoid spina bifida to avoid having a child with disabilities does not imply that if that outcome should occur, the child will be unwanted, rejected, or loved less." 128 The disability is not equivalent to the person with the disability, a point that, ironically, disability rights activists have themselves been emphasizing for years.

It is difficult to judge which is the stronger argument. Does routine prenatal genetic testing denigrate the value of the lives of people with disabilities or not? In reading the very thoughtful contributions to the volume assembled by the Hasting Center project, I found myself swayed by each view. The critics of testing are surely right that given the history of the misuse of genetic information, it is significant that detecting genetic disease in utero so as to facilitate abortion has become so common and seemingly important. Underlying this practice may be the view that disabilities are so terrible that an otherwise wanted child should be aborted if she will be disabled. ${ }^{129}$ While this view of disability and its significance both for the child and for the parent is a comment on the disability more than the child, is it so disconnected from a comment on the value of life with a disability and, thus, of the life of the person with the disability? The fact that prenatal genetic testing has

\footnotetext{
124 James Lindemann Nelson, The Meaning of the Act: Reflections on the Expressive Force of Reproductive Decision Making and Policies, in PRENATAL TESTING, supra note 10, at 196, 211.

125 Id. at 196-97.

126 See, e.g., Bonnie Steinbock, Disability, Prenatal Testing, and Selective Abortion, in PrENATAL TESTING, supra note 10, at 108, 120-21.

127 Kittay \& Kittay, supra note 114, at 187.

128 Bonnie Steinbock, supra note 126, at 121.

129 I have avoided drawing distinctions among disabilities as disability activists who critque prenatal genetic testing avoid making these distinctions.
} 
become so routine and invisible bespeaks a failure of imagination-an inability to envision the lives of disabled persons as rich and meaningful. ${ }^{130}$ In reading the Hastings Center volume, as well as Michael Berube's book about his son who has Down's Syndrome (a book which stretches that imagination), ${ }^{131}$ I find myself very close to being persuaded by the critics of testing. And yet, not fully so.

\section{Fixing the Meaning of a Practice: "Justice Is Conflict"}

How does this discussion of whether prenatal genetic testing and selective abortion expresses denigration of people with disabilities help to advance the inquiry into whether genetic discrimination against living people denigrates the worth of people with genetic predispositions to disease? In one sense, the case for a denigrating meaning is clearer in the prenatal testing example in that the practice at issue determines criteria for selective abortions-quite literally, criteria for being born. If it is not clear that this practice denigrates the lives of people with genetic disease, one might think it is unlikely that a practice that instead affects insurance and employment would be denigrating. On the other hand, in the prenatal testing example, it is not clear that selective abortion expresses anything about the worth of living people with disabilities. Rather, to the extent that it says something, it may be something about the value of the disability rather than the person. In contrast, genetic discrimination in insurance, employment or elsewhere does not have this problem because it directly affects the lives of living persons with genetic conditions. To the extent that it says something, it does so about the lives of living people with genetic conditions.

In both examples, the process of determining what a practice expresses, if it expresses a meaning at all, is not an easy task. As the counter-critics described above noted, when there is no well-recognized code to use in determining the expressive significance of action, it is difficult to say if that action expresses anything. But this is not reason to abandon the task. In discussions about literature, movies or art, we routinely disagree about what meanings a book, film or painting expresses. There is also no agreed-upon code for determining such meanings. While a language itself may be such a code, a scene about a particular subject, to which literary critics of the professional and armchair variety routinely attach meanings, are not accompanied by a code that instructs that scenes about $\mathrm{X}$ signify Y.

Most importantly, if the expressive theory of discrimination is right about what makes a policy or social practice discriminatory, then we have no alternative but to try to determine the meaning of practices like genetic discrimination and prenatal genetic testing. The expressive account of when discrimination is wrong instructs one to judge whether a policy or law impermissibly discriminates by looking at the expressive dimension of the policy or law. If it expresses denigration-that is, if its meaning conflicts with the claim that each person is equally worthy of concern and respect-then that policy discriminates wrongfully. To make this judgment, one must do the best one can to determine the meaning of the policy, law or practice at issue.

130 This failure of imagination especially applies to persons with Down's Syndrome. See Parens \& Asche, supra note 121, at 7-8 (discussing the attitudes of obstetricians and genetic counselors to patients who have received a prenatal diagnosis of Down's Syndrome).

131 Michael Bérubé, LIFE As We KnOW IT (1996). 
Does the difficulty in determining the meaning of the policy, law or practice point to a failure of the expressive theory itself, thereby making this particular argument about why genetic discrimination is wrong misguided from the start? I think not. Interpreting social practices, like interpreting art and literature, is an exercise in which our diverse histories, cultures and experiences are critically important. If diversity among people is deep, then there are bound to be significant disagreements when intellectual tasks draw upon that diversity. But perhaps this disagreement is not problematic for the just resolution of social issues. The philosopher Stuart Hampshire believes, for example, that conflict is a persistent feature of both society and the mind precisely because of the profound diversity among people. ${ }^{132}$ The only universally acknowledged value, in his view, is a commitment to procedural fairness, which he understands quite minimally. ${ }^{133}$ For Hampshire, procedural fairness requires only that a procedure afford each side to a conflict the opportunity to be heard. ${ }^{134}$ If Hampshire is right, both about the persistence of conflict and the significance of procedural fairness, then what is most important is that our society provides opportunities to listen and hear the views of many people regarding what the practice of genetic discrimination expresses. This may be the best we can do in assessing whether genetic discrimination is wrong. If Hampshire is right, actually doing just that is an important act of securing social justice. As Hampshire explains:

Neither in a social order, nor in the experience of an individual, is a state of conflict the sign of a vice, or a defect, or a malfunctioning. It is not a deviation from the normal state of a city or of a nation, and it is not a deviation from the normal course of a person's experience. To follow through the ethical implications of these propositions about the normality of conflict, these Heracleitean truths, a kind of moral conversion is needed, a new way of looking at all the virtues, including the virtue of justice. We need to turn around the mirror of theory, so that we see ourselves both as we are and as we have been. ${ }^{135}$

The argument that genetic discrimination is meaningfully different from discrimination on the basis of health because of what it expresses is thus an argument about which I cannot reach a final conclusion. Whether genetic discrimination wrongfully discriminates depends on whether such discrimination expresses that people with serious genetic conditions are less worthy of concern or respect. The history of eugenics in western society is relevant to that question and surely makes this claim plausible. As Professor Eva Feder Kittay emphasizes in the context of prenatal genetic testing, however, if context seems to do all the work, then it is hard to say that the particular practice under discussion expresses anything at all. $^{136}$

132 StUART HampShIRE, JUSTICE IS CONFLICT 37 (2000) (arguing that "the diversity and divisiveness of languages and of cultures and of local loyalties is not a superficial but an essential and deep feature of human nature-both unavoidable and desirable-and rooted in our divergent imaginations and memories").

$133 I$ d. at 4 (asserting that "fairness in procedures for resolving conflicts is the fundamental kind of fairness, and that it is acknowledged as a value in most cultures, places, and times: fairness in procedure is an invariable value, a constant in human nature").

134 Id. at 8 (identifying a key feature of procedural fairness as "audi alteram pertem ("hear the other side')").

135 Id. at 33-34

136 Kittay \& Kittay, supra note 114 , at 187-92. 
This examination of the expressivist argument in support of special legislation prohibiting genetic discrimination demonstrates the importance of grappling with the social meaning of genetic discrimination. It instructs that decisions by states and the federal government regarding whether to enact such legislation ought to focus on the question of what the practice of genetic discrimination by insurers, employers and others expresses about the equal worth of persons with a genetic predisposition to significant disease. We should also keep in mind that this is a question to which the answer may vary depending on whether the discrimination occurs in health insurance, life and disability insurance or in family contexts. Moreover, if Hampshire is right that it is the process of listening to the "other side" that is centrally important to acting justly, perhaps the most important step is ensuring that these questions are addressed in fora that provide opportunities for many voices to be heard.

\section{OTHER CONCERNS ABOUT EXPRESSION}

Some commentators have pointed out that the passage of laws forbidding genetic discrimination may have the unfortunate consequence of reinforcing the public perception that genetic endowments determine destiny. The laws may communicate that genetics is different and significant in ways that are misleading and dangerous. ${ }^{137}$ Thomas Murray captures this point well: "The more we repeat that genetic information is fundamentally unlike other kinds of medical information, the more support we implicitly provide for genetic determinism, and for the notion that genetics exerts special power over our lives."138 This concern points out an important drawback of special genetics legislation that is worth considering. Before considering it, however, it is important to note the ways in which it differs from the argument explored in this Article.

The claim that genetic discrimination is wrong because it expresses denigration builds on the argument that there are limits on what one ought to express. One ought not (and governments especially ought not) act in a way that express that some people are less worthy of concern and respect than others. This argument does not tell us what we ought to express, rather it merely tells us what we may not. Within the realm of permissible actions (i.e., ones that do not express denigration in ways ruled out by the equal concern and respect principle), some of those actions will be better and worse for the people affected for a variety of reasons.

Murray and others who point out that special genetics legislation may reinforce attitudes that are inaccurate and harmful do not claim that this expressive dimension of the state's action (passing the law) conflicts with any principle that limits expressive action. Rather, they argue that the laws are unwise because they express an unfortunate meaning. ${ }^{139}$ This is a policy argument about how best to change attitudes, not an argument about what practices violate the principles that ought to guide action.

137 Greely, supra note 13, at 1494 (arguing that "[b]y telling people that their genetic variations are so important-are the equivalents of race, sex, religion, and other suspect classifications-we encourage them to believe that it is true, in ways that are both inaccurate and pernicious"); Murray, supra note 12, at 71; Suter, supra note 7, at 740 (concluding that by "responding to the public's fears with special protections for genetic information, genetics legislation may validate and fucl the flames of these fears as well as the underlying perspective that generates those fears").

138 Murray, supra note 12, at 71.

139 See supra notes $137-138$ and accompanying text. 
That said, how should we weigh their concern? First, if we believe that rights claims trump policy considerations, then their argument must give way to the argument of this section if we conclude that genetic discrimination does indeed denigrate people with genetic disease. In addition, like most policy arguments, it must be balanced against the other important policies to be considered. The most pressing policy consideration to be weighed on the other side is the one considered in the previous section-that laws forbidding genetic discrimination promote health.

\section{LINKING DEFINITION WITH JUSTIFICATION}

Finally, we must make sure that the reasons to support legislation forbidding genetic discrimination do in fact justify prohibiting genetic discrimination as earlier defined. Recall that in response to the difficulty delineating genetic discrimination from discrimination on the basis of health, this Article adopted Professor Henry Greely's proposed solution. Greely suggests that genetic discrimination be defined as discrimination on the basis of information about genotype, whatever the source of that information, whether it is sophisticated DNA analysis or the familiar family history solicited by a physician. However, once a person manifests disease whether that disease is of genetic, non-genetic or mixed origin, discrimination on this basis would not be considered genetic discrimination. It is this definition of genetic discrimination that we must examine to ensure that the reasons to prohibit genetic discrimination that have been examined in this Article make sense when genetic discrimination is so defined.

Of the many reasons that have been offered in support of prohibiting genetic discrimination, it is only the two discussed in detail above that remain plausible candidates for reasons to distinguish genetic discrimination from health-status discrimination. To recap, genetic discrimination may be different and thereby warrant special legislation in order to ensure that the health benefits of genetic science are realized. Second, genetic discrimination may be meaningfully different from health-based discrimination because it expresses denigration of people with genetic disease. Next, we must ensure that these reasons support prohibiting genetic discrimination as defined in this Article. In other words, does discrimination on the basis of genotype express denigration that discrimination on the basis of phenotype does not? Will forbidding discrimination on the basis of genotype remove barriers to reaping the health benefits of genetic science and will it do so more than would forbidding discrimination on the basis of phenotype?

The answer to each of these questions is quite plausibly yes. In the case of the expressive significance of discrimination, when the discrimination is based on an asymptomatic genetic condition, it is likely that such discrimination will be seen to be especially genetic, thereby recalling all of the history of eugenics in our collective consciousness. In the case of the argument based on the promotion of health, it is only those individuals without manifest disease for whom genetic testing will provide new information that may be useful in either therapy or research. It makes sense to target this group because it is this group that may be discouraged from testing without protective legislation.

\section{CONCLUSION: AGENDA FOR RESEARCH AND DISCUSSION}

In conclusion, it will be helpful to review the questions that warrant further discussion or research. With regard to the expressive argument in favor of prohibiting genetic discrimination, this Article stresses the importance of continuing 
the discussion, in public fora as well as in private conversation, regarding whether genetic discrimination denigrates the worth of people with genetic disease. In order to ensure that this argument tracks the definition of genetic discrimination adopted here, this discussion must focus on whether discrimination on the basis of unexpressed information about genotype is especially denigrating and whether it is meaningfully different from the social meaning of discrimination on the basis of expressed disease, whether of a genetic or non-genetic etiology.

In examining the argument that protection from genetic discrimination will enhance health, this Article uncovered several empirical questions that require further study. First, if people refrain from genetic testing because they fear genetic discrimination, one must ascertain in what contexts people fear genetic discrimination-in health insurance, life and disability insurance, employment or family law contexts, or family and private life. This determination is important because if prohibitions on discrimination are to succeed in assuaging the concerns that cause people to decline testing, this legislation must prohibit what people actually fear. Second, if people fear discrimination in multiple contexts, researchers must determine whether limited legislation that reaches only health insurance and employment would be sufficient to affect decision-making about testing. The Hall and Rich study described earlier begins to answer these questions. ${ }^{40}$ Further research must work both to confirm and build upon their results. Third, if the promotion of health is the main goal, one must try to determine whether legislation prohibiting genetic discrimination would in fact promote health more than legislation prohibiting general health-status discrimination. If not, health promotion would not be a sufficient reason for genetic, as opposed to generic, legislation.

Finally, one must try to determine how legislation prohibiting genetic discrimination in health insurance is likely to affect the receptiveness of the body politic to universal healthcare coverage. This is important because ensuring healthcare for all will surely enhance health and because if genetics legislation will make universal coverage less likely, then the passage of genetics legislation may deepen inequality.

140 See supra text accompanying notes $70-75$. 